\title{
Effectiveness of phosphonium cation-based ionic liquids as lubricant additive
}

\author{
R. González ${ }^{\mathrm{a}, \mathrm{d}}$, M. Bartoloméa ${ }^{\mathrm{a}}$, D. Blanco ${ }^{\mathrm{b}}$, J.L. Viesca ${ }^{\mathrm{b}, \mathrm{d}}$ \\ A. Fernández-González ${ }^{\mathrm{c}}, \mathrm{A}$. Hernández Battez ${ }^{\mathrm{b}, \mathrm{d}^{*}}$ \\ ${ }^{\mathrm{a}}$ Department of Marine Science and Technology, University of Oviedo, Asturias, Spain \\ ${ }^{\mathbf{b}}$ Department of Construction and Manufacturing Engineering, University of Oviedo, Asturias, Spain \\ ${ }^{c}$ Department of Physical and Analytical Chemistry, University of Oviedo, Asturias, Spain \\ ${ }^{\mathrm{d}}$ Faculty of Science \& Technology, Bournemouth University, UK \\ ${ }^{(*)}$ Email: aehernandez@uniovi.es
}

\begin{abstract}
Two phosphonium cation-based ionic liquids (ILs) were studied as additive to a mineral oil. Solubility tests and TGA of neat samples were performed. Three concentrations of the ILs were used in the tribological tests. Base oil-ZDDP mixtures were used as comparison samples. Tribological tests were made using a reciprocating ball-on-disc configuration. Load ramp and Stribeck curve tests were also performed. The worn surface was studied by different techniques. The results showed similar and better friction reduction properties for ILs- or ZDDP-containing mixtures than the neat base oil. The $\left[\mathrm{P}_{66614}\right]\left[(\mathrm{iC} 8)_{2} \mathrm{PO}_{2}\right]$-containing mixtures outperformed the antiwear behavior of the other samples. XPS results showed different mechanisms of lubrication when using ILs or ZDDP.
\end{abstract}

Keywords: phosphonium cation-based ionic liquids; additive; friction; wear

\section{Introduction}

Ionic liquids (ILs) were initially developed for use as electrolytes in batteries. Their potential value provoked in subsequent years a significant increase of research in diverse industrial applications such as catalysts, liquid crystals, extraction technology, synthesis and green solvents [1-3]. In addition, tribology interest in ionic liquids has also grown this century due to their unusual properties, which meet the requirements of high-performance lubricants [4]. These molten salts are usually called "green" lubricants because of their main properties: non-volatility, non-flammability, high thermo-oxidative stability, ashless character, high ionic conductivity and controlled miscibility with organic compounds, which enhance their potential performance in lubrication science [5-11]. Early works dealt with ILs with the imidazolium cation and fluorine-containing anions [12-16], but these anions tend to produce toxic and corrosion products in the presence of water [17]. The good lubricating properties of ILs are related to its polarity [18] and reactivity provoking the formation of adsorbed tribofilms on the metal surfaces and contributing to friction and wear reduction [19-21].

Due to the common inherent insolubility of ILs in non-polar hydrocarbon oils, a lot of research using ILs as a lubricant additive in very low concentrations or in oil-IL emulsions has been developed over the last decades [22-32]. In general, better compatibility was found when these substances were mixed with polar 
base oils such as polyethylene glycol [33-36], ester [18, 30, 37] or glycerol [38-40]. The growing applications [41-42]. From a tribological perspective, some phosphonium cation-based ionic liquids have shown good performance as lubricant additive due to their solubility in oils [28-29, 43]. The main publications about phosphonium ILs as a lubricant additive are summarized in Table 1.

Some authors have worked with several phosphonium-based ionic liquids, mostly used as lubricant additive [28-29, 43-45]. Barhill et al. [43] studied five ILs with the same anion but different phosphonium cations $\left(\left[\mathrm{P}_{8888}\right][\mathrm{DEHP}], \quad\left[\mathrm{P}_{66614}\right][\mathrm{DEHP}], \quad\left[\mathrm{P}_{44414}\right][\mathrm{DEHP}], \quad\left[\mathrm{P}_{4444}\right][\mathrm{DEHP}] \quad\right.$ and $\left[\mathrm{P}_{4448}\right][\mathrm{DEHP}]$ ) in order to use them as antiwear additive in one synthetic base oil. Ball-on-flat (AISI 52100 steel ball against an iron flat) tests were carried out at $100^{\circ} \mathrm{C}, 100 \mathrm{~N}$ of normal load, a total sliding distance of $1000 \mathrm{~m}, 10 \mathrm{~Hz}$ frequency and $10 \mathrm{~mm}$ of stroke length. They found that the symmetry and short alkyl chains in the cation produce a higher density and thermal stability because of the closer packing. In addition, an increase in the cation size usually causes a rise in the solubility of an IL in nonpolar hydrocarbon oils, ensuring full solubility above a length of 6 carbons. The two soluble ILs $\left(\left[\mathrm{P}_{8888}\right][\mathrm{DEHP}]\right.$ and $\left.\left[\mathrm{P}_{66614}\right][\mathrm{DEHP}]\right)$ provided effective wear protection when added to the base oil due to tribofilm formation, the symmetric one being the best choice. Qu et al. [44] compared the tribological behavior of the $\left[\mathrm{P}_{66614}\right][\mathrm{DEHP}]$ ionic liquid versus the traditional additive ZDDP, both at $1.0 \mathrm{wt} \%$ in PAO 4 base oil. The high-frequency reciprocating sliding tests were conducted facing piston top rings (with a plasma-sprayed coating) and iron cylinder liners (grey cast iron) at $100^{\circ} \mathrm{C}$ and room temperature. Although the tribological performance of both additives were similar at room-temperature tests, the antiwear performance of $\left[\mathrm{P}_{66614}\right][\mathrm{DEHP}]$ at $100^{\circ} \mathrm{C}$ was much better than that of ZDDP. Zhou et al. [45] studied the following ILs: $\left[\mathrm{P}_{4444}\right][\mathrm{BEHP}],\left[\mathrm{P}_{66614}\right][\mathrm{BEHP}],\left[\mathrm{P}_{66614}\right]\left[\mathrm{i}-\mathrm{C}_{7} \mathrm{H}_{15} \mathrm{COO}\right],\left[\mathrm{P}_{66614}\right]\left[\mathrm{n}-\mathrm{C}_{7} \mathrm{H}_{15} \mathrm{COO}\right]$, $\left[\mathrm{P}_{66614}\right]\left[\mathrm{i}-\mathrm{C}_{9} \mathrm{H}_{19} \mathrm{COO}\right],\left[\mathrm{P}_{66614}\right]\left[\mathrm{n}-\mathrm{C}_{9} \mathrm{H}_{19} \mathrm{COO}\right],\left[\mathrm{P}_{66614}\right]\left[\mathrm{n}-\mathrm{C}_{17} \mathrm{H}_{35} \mathrm{COO}\right]$ and $\left[\mathrm{P}_{66614}\right]\left[\mathrm{RSO}_{3}\right]$ as lubricant additive in a polyalphaolefin (PAO 4), ensuring that the P concentration in the blends does not exceed the upper limit settled in engine specifications $(800 \mathrm{ppm})$. The tribological tests were carried out under the same testing conditions used in a previous publication [45]. The results showed that longer and branched alkyls chains in the cation usually improve the solubility in non-polar oils; while from a tribological point of view, the wear protection effectiveness was better for the two ionic liquids with organophosphate anion. Unlike most ionic liquids, which are insoluble in non-polar hydrocarbon oils, the phosphoniumbased ILs with three-dimensional quaternary structures and high steric hindrance (long hydrocarbon 
chains) dilute the charge of the ions and therefore improve the compatibility with neutral oil molecules, synergistic effects using phosphonium-based ILs and traditional ZDDP combined as lubricant additives, obtaining around $70 \%$ and $30 \%$ of wear and friction reductions, respectively, due to an important increase of the reactive elements in the tribofilm.

Totolin et al. [47] also stated that the corrosion and limited solubility in non-polar hydrocarbon oils represent the main issues for the use of ILs in lubrication. They studied the tribological performance under boundary lubrication conditions of several oil-IL mixtures in steel-steel contact. One phosphonium-based halogen-free IL was included in the study, the mixtures made with phosphonium phosphate IL as additive significantly reduced the friction and wear of the steel surfaces by forming a phosphate layer on the wear scar. Although friction with a mixture containing a $\mathrm{NTf}_{2}$ anion-based IL was relatively similar to that with the mixture with phosphate anion-based IL, the results indicated that the tribochemical reaction of the $\mathrm{NTf}_{2}$ anion has a negative impact on wear due to the presence of corrosion. Otero et al. [48] tested the solubility of several ILs in different base oils (three esters and one vegetable oil) in order to check their behavior as antifriction and antiwear additives for steel-steel contact. Only two phosphonium based ILs $\left(\left[\mathrm{P}_{4442}\right]\left[\mathrm{C}_{2} \mathrm{C}_{2} \mathrm{PO}_{4}\right]\right.$ and $\left.\left[\mathrm{P}_{66614}\right]\left[\left(\mathrm{C}_{2} \mathrm{~F}_{5}\right)_{3} \mathrm{PF}_{3}\right]\right)$ had the necessary solubility to achieve 1 wt $\%$ oil-IL blends in the lubrication of this tribological pair (AISI 420 steel/100Cr6 steel) under loads of 14 and $22 \mathrm{~N}$ (corresponding to mean pressures of 1.6 and $1.86 \mathrm{GPa}$, respectively). The base oils and the ILs blends were characterized in terms of density, viscosity and thermal stability. XPS spectra showed a phosphorus tribofilm on the worn surface lubricated with mixtures containing $\left[\mathrm{P}_{4442}\right]\left[\mathrm{C}_{2} \mathrm{C}_{2} \mathrm{PO}_{4}\right]$, much more significant than that detected with $\left[\mathrm{P}_{66614}\right]\left[\left(\mathrm{C}_{2} \mathrm{~F}_{5}\right)_{3} \mathrm{PF}_{3}\right]$ counterparts, making the $\left[\mathrm{P}_{4442}\right]\left[\mathrm{C}_{2} \mathrm{C}_{2} \mathrm{PO}_{4}\right]$ an excellent antifriction and antiwear additive for the base oils used.

Somers et al. [30] tested the lubrication of steel-aluminum contacts using 7 different phosphonium cation-based ionic liquids $\quad\left(\left[\mathrm{P}_{66614}\right][\mathrm{BEHP}], \quad\left[\mathrm{P}_{66614}\right] \quad\left[(\mathrm{iC} 8)_{2} \mathrm{PO}_{2}\right], \quad\left[\mathrm{P}_{66614}\right][\mathrm{SSi}], \quad\left[\mathrm{P}_{66614}\right][\mathrm{DPP}]\right.$, $\left[\mathrm{P}_{66614}\right]\left[\mathrm{NTf}_{2}\right],\left[\mathrm{P}_{66614}\right][\mathrm{FAP}]$ and $\left.\left[\mathrm{P}_{1444}\right][\mathrm{DPP}]\right)$ as additive to several polar and non-polar base oils. They stated that most phosphonium cation-based ILs were soluble in polar base oils such as vegetable oil. On the other hand, solubility in non-polar base oils such as mineral oil was favored by ion pairing and long alkyl chains on both ions. From a tribological point of view, the performance of the mixtures was dependent on the performance of the base oils. In wear tests, the blends were tested at 5 and $10 \mathrm{~N}$, at a speed of $0.2 \mathrm{~m} / \mathrm{s}$ for $500 \mathrm{~m}$, with IL concentrations ranging between 0.01 and $0.2 \mathrm{~mol} / \mathrm{kg}$. In polar base 
oils, relatively large amounts of IL $(0.2 \mathrm{~mol} / \mathrm{kg})$ were required to achieve a significant reduction of the wear depth as well as the friction at a $5 \mathrm{~N}$ load. On the other hand, drastic reductions in aluminum wear at $10 \mathrm{~N}$ resulted with smaller amounts of IL $(0.01 \mathrm{~mol} / \mathrm{kg})$ by using non-polar base oils. Analyzing the wear track by XPS suggested that the formation of tribofilms has an important role in the observed friction and wear reduction, with the better tribological performance found for the mineral oil with $\left[\mathrm{P}_{66614}\right]$ $\left[(\mathrm{iC} 8)_{2} \mathrm{PO}_{2}\right]$ ionic liquid as additive. Khemchandani et al. [49] investigated two phosphonium based ILs $\left(\left[\mathrm{P}_{1444}\right][\mathrm{DPP}]\right.$ and $\left.\left[\mathrm{P}_{66614}\right][\mathrm{DPP}]\right)$ as antiwear additive and compared them against a commonly used Amine Phosphate (AP) additive in biodegradable lubricants. Experiments were carried out at $40 \mathrm{~N}$ loads with contact pressure of $2.27 \mathrm{GPa}$ and a speed of $0.1 \mathrm{~m} / \mathrm{s}$ with a sliding distance of $1000 \mathrm{~m}$. The two ILs (concentration of $0.005 \mathrm{~mol} / \mathrm{kg}$ ) replaced the AP in the three biodegradable base stocks formulation. Results indicated that the film formed by $\left[\mathrm{P}_{1444}\right][\mathrm{DPP}]$ protects the surface much better than the other two choices, showing good load carrying capacity.

Some papers mentioned above [28-30, 43-49] studied the behavior of phosphonium ionic liquids as lubricant additive in different material pairs. However, nothing in the literature deals with the effectiveness of using these two phosphonium cation-based ILs $\left(\left[\mathrm{P}_{66614}\right]\left[(\mathrm{iC} 8)_{2} \mathrm{PO}_{2}\right]\right.$ and $\left.\left[\mathrm{P}_{66614}\right][\mathrm{BEHP}]\right)$ as a lubricant additive in a mineral base oil for steel-steel contact. The present paper studies the tribological behavior of these two ILs as additive in a mineral oil and compares this with samples containing ZDDP. The concentration of ionic liquids and ZDDP in the mixture took into account current and future engine oil specifications (PC-11, ILSAC GF-5 and ILSAC GF-6) that recommend operating under $800 \mathrm{ppm}$ of phosphorus concentration [50]. 
Table 1. Phosphonium cation-based ILs used as lubricant additive.

\begin{tabular}{|c|c|c|c|c|}
\hline $\begin{array}{l}\text { Phosphonium } \\
\text { based ionic liquids }\end{array}$ & Contact materials & Tribological tests & Function of ILs & References \\
\hline$\left[\mathrm{P}_{66614}\right][\mathrm{BEHP}]$ & $\begin{array}{l}\text { Engine Piston Top Rings } \\
\text { Iron cylinder liners }\end{array}$ & $\begin{array}{l}\text { Reciprocating } \\
\text { sliding test }\end{array}$ & $\begin{array}{c}\text { Additives } \\
\text { (1 wt\% IL, 5\% IL \& 1\% ZDDP) }\end{array}$ & {$[28,44]$} \\
\hline $\begin{array}{c}{\left[\mathrm{P}_{66614}\right][\mathrm{BEHP}],\left[\mathrm{P}_{66614}\right]\left[\left(\mathrm{iC}_{8}\right)_{2} \mathrm{PO}_{2}\right]} \\
{\left[\mathrm{P}_{66614}\right][\mathrm{DBP}],\left[\mathrm{P}_{66614}\right]\left[\mathrm{C}_{8} \mathrm{C}_{8} \mathrm{PS}_{2}\right]}\end{array}$ & $\begin{array}{l}\text { SAE9254 Engine Piston Top } \\
\text { Rings } \\
\text { Iron cylinder liners }\end{array}$ & $\begin{array}{l}\text { Reciprocating } \\
\text { sliding test }\end{array}$ & Additive (5 wt $\%$ into 3 base oils) & {$[29]$} \\
\hline $\begin{array}{c}{\left[\mathrm{P}_{66614}\right][\mathrm{BEHP}]} \\
{\left[\mathrm{P}_{66614}\right]\left[\left(\mathrm{iC}_{8}\right)_{2} \mathrm{PO}_{2}\right],\left[\mathrm{P}_{66614}\right][\mathrm{SSi}]} \\
{\left[\mathrm{P}_{66614}\right][\mathrm{DPP}],\left[\mathrm{P}_{66614}\right]\left[\mathrm{NTf}_{2}\right]} \\
{\left[\mathrm{P}_{66614}\right][\mathrm{FAP}],\left[\mathrm{P}_{1444}\right][\mathrm{DPP}]}\end{array}$ & $\begin{array}{l}\text { 100Cr6 Steel balls } \\
\text { Aluminum AA2024 disks }\end{array}$ & Pin on Disk & Additive (8--16 wt\% into 3 base oils) & {$[30]$} \\
\hline $\begin{array}{c}{\left[\mathrm{P}_{66614}\right][\mathrm{BEHP}],\left[\mathrm{P}_{4444}\right][\mathrm{BEHP}],\left[\mathrm{P}_{4448}\right][\mathrm{BEHP}]} \\
{\left[\mathrm{P}_{44414}\right][\mathrm{BEHP}],\left[\mathrm{P}_{8888}\right][\mathrm{BEHP}]}\end{array}$ & $\begin{array}{l}\text { AISI } 52100 \text { Steel ball } \\
\text { CL35 Iron Flat }\end{array}$ & $\begin{array}{l}\text { Reciprocating } \\
\text { Ball on Flat }\end{array}$ & Additive $(0.08 \mathrm{wt} \% \mathrm{P})$ & {$[43]$} \\
\hline $\begin{array}{c}{\left[\mathrm{P}_{4444}\right][\mathrm{BEHP}],\left[\mathrm{P}_{66614}\right][\mathrm{BEHP}],\left[\mathrm{P}_{66614}\right]\left[\mathrm{i}-\mathrm{C}_{7} \mathrm{H}_{15} \mathrm{COO}\right]} \\
{\left[\mathrm{P}_{66614}\right]\left[\mathrm{n}-\mathrm{C}_{7} \mathrm{H}_{15} \mathrm{COO}\right],\left[\mathrm{P}_{66614}\right]\left[\mathrm{i}-\mathrm{C}_{9} \mathrm{H}_{19} \mathrm{COO}\right]} \\
{\left[\mathrm{P}_{66614}\right]\left[\mathrm{n}-\mathrm{C}_{9} \mathrm{H}_{19} \mathrm{COO}\right],\left[\mathrm{P}_{66614}\right]\left[\mathrm{n}-\mathrm{C}_{17} \mathrm{H}_{35} \mathrm{COO}\right]} \\
{\left[\mathrm{P}_{66614}\right]\left[\mathrm{RSO}_{3}\right]}\end{array}$ & $\begin{array}{l}\text { AISI } 52100 \text { hardened steel ball } \\
\text { CL35 Iron Flat }\end{array}$ & $\begin{array}{l}\text { Reciprocating } \\
\text { Ball on Flat }\end{array}$ & Additive ( 0.75 to $2.44 \mathrm{wt} \%$ into PAO) & {$[45]$} \\
\hline$\left[\mathrm{P}_{4441}\right][\mathrm{DMP}]$ & $\begin{array}{l}\text { AISI } 52100 \text { Balls } \\
\text { AISI } 52100 \text { Discs }\end{array}$ & SRV Ball of Flat & Additive $(0.7,1.5$ and $3.4 \mathrm{wt} \%)$ & {$[47]$} \\
\hline $\begin{array}{c}{\left[\mathrm{P}_{66614}\right]\left[\left(\mathrm{C}_{2} \mathrm{~F}_{5}\right)_{3} \mathrm{PF}_{3}\right]} \\
{\left[\mathrm{P}_{4442}\right]\left[\mathrm{C}_{2} \mathrm{C}_{2} \mathrm{PO}_{4}\right]}\end{array}$ & $\begin{array}{l}\text { 100Cr6 Steel balls } \\
\text { AISI } 420 \text { stainless steel plate }\end{array}$ & $\begin{array}{l}\text { Reciprocating } \\
\text { Ball on Plate }\end{array}$ & $\begin{array}{c}\text { Additive ( } 1 \text { wt } \% \text { into } 4 \text { base oils, } 1 \mathrm{wt} \% \\
\text { ZDDP) }\end{array}$ & {$[48]$} \\
\hline$\left[\mathrm{P}_{1444}\right][\mathrm{DPP}],\left[\mathrm{P}_{66614}\right][\mathrm{DPP}]$ & $\begin{array}{l}\text { 100Cr6 Steel balls } \\
\text { AISI } 52100 \text { steel disk }\end{array}$ & Pin on Disk & Additive ( $0.05 \mathrm{~mol} / \mathrm{kg}$ into 3 base oils) & [49] \\
\hline
\end{tabular}




\section{Experimental details}

\subsection{Ionic liquids and base oils}

The phosphonium cation-based ionic liquids, $\left[\mathrm{P}_{66614}\right][\mathrm{BEHP}]$ and $\left[\mathrm{P}_{66614}\right]\left[(\mathrm{iC} 8)_{2} \mathrm{PO}_{2}\right]$, used as additive in this research were provided by Io-Li-Tec (Ionic Liquid Technologies GmbH ). The base oil (YUBASE) was kindly supplied by Repsol, S.A, as well as the traditional oil additive zinc dialkyldithiophosphate (ZDDP). Table 2 shows the chemical properties of the fluids used.

Table 2. Material properties.

Materials

\begin{tabular}{lcccc}
\hline \multirow{2}{*}{ Base Oils / Additive / ILs } & $\begin{array}{c}\text { Density }\left(\mathrm{g} / \mathrm{cm}^{3}\right) \\
\text { ASTM D 4052 }\left(15^{\circ} \mathrm{C}\right)\end{array}$ & \multicolumn{2}{c}{ Kinematic viscosity $\left(\mathrm{mm}^{2} / \mathrm{s}\right)$} & \multirow{2}{*}{$\begin{array}{c}\text { Viscosity Index } \\
\text { ASTM D 445 }\end{array}$} \\
\cline { 3 - 4 } & & $40{ }^{\circ} \mathrm{C}$ & $100{ }^{\circ} \mathrm{C}$ & \\
\hline YUBASE & 0.8338 & 19.57 & 4.23 & 122 \\
\hline ZDDP & 2.320 & 320 & 14 & 169 \\
\hline$\left[\mathrm{P}_{66614}\right]\left[(\mathrm{iC} 8)_{2} \mathrm{PO}_{2}\right]$ & 0.8899 & 528.93 & 55.06 & 181 \\
{$\left[\mathrm{P}_{66614}\right][\mathrm{BEHP}]$} & 0.915 & 528.05 & 59.00 & \\
\hline
\end{tabular}

Ionic Liquids

\begin{tabular}{cccc}
\hline IUPAC Name \& Chemical Structure & Purity (\%) & $\begin{array}{c}\text { Molecular } \\
\text { Weight }\end{array}$ & $\begin{array}{c}\text { Empirical } \\
\text { Formula }\end{array}$ \\
\hline
\end{tabular}

Trihexyltetradecylphosphonium bis(2,4,4-trimethylpentyl) phosphinate $\left[\mathrm{P}_{66614}\right]\left[(\mathrm{iC} 8)_{2} \mathrm{PO}_{2}\right]$

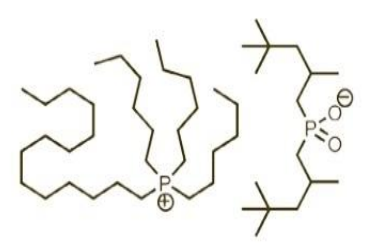

Trihexyltetradecylphosphonium bis(2-ethylhexyl)phosphate

$$
\left[\mathrm{P}_{66614}\right][\mathrm{BEHP}]
$$

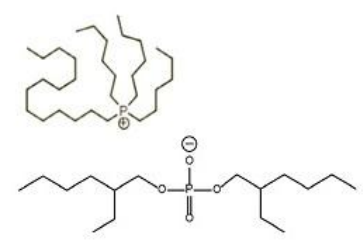

Mixtures of the base oil and the ionic liquids were prepared using $0.25,0.5$ and 1 wt $\%$ of IL, corresponding with a phosphorus concentration of $179.25,358.5$ and $717 \mathrm{ppm}$ for $\left[\mathrm{P}_{66614}\right][\mathrm{BEHP}]$ and 175, 350 and $700 \mathrm{ppm}$ for $\left[\mathrm{P}_{66614}\right]\left[(\mathrm{iC} 8)_{2} \mathrm{PO}_{2}\right]$, respectively. On the other hand, $0.2,0.4$ and $0.8 \mathrm{wt} \%$ of 
ZDDP (corresponding to $175.75,351.5$ and 703 ppm of phosphorus concentration) were separately added

\subsection{Physicochemical properties}

Samples for solubility tests were prepared as follows: $1 \mathrm{~mL}$ ionic liquid was dropped onto $2 \mathrm{~mL}$ of base oil and vortexed in a Labonet VX 100 Vortex until obtaining a homogeneous suspension to ensure saturation of the ionic liquid in the base oil. Then, the mixture was centrifuged at $5300 \mathrm{rpm}$ for five minutes in a Thermo electron corporation Heraeus Labofuge 200 centrifuge. The less dense phase (base oil) was decanted and digested with $65 \% \mathrm{HNO}_{3}: 25 \% \mathrm{H}_{2} \mathrm{O}_{2}$ 7:1 in a microwave oven, diluting the residue as necessary in order to analyze it by ICP-MS, but the densest phase was discarded. Analyzing the results obtained, $\left[\mathrm{P}_{66614}\right]\left[(\mathrm{iC} 8)_{2} \mathrm{PO}_{2}\right]$ showed a concentration value (maximum solubility) close to 23 wt. $\%$ in the base oil, while the value exhibited for $\left[\mathrm{P}_{66614}\right][\mathrm{BEHP}]$ was about $13 \mathrm{wt} . \%$. This methodology is similar to that used by Otero et al. [48].

Thermogravimetric analysis (TGA) was used to determine the decomposition temperatures of the ionic liquids and base oil. Dynamic tests were made on a Mettler Toledo TGA/SDTA851 from room temperature to approximately $600^{\circ} \mathrm{C}$ at a $10{ }^{\circ} \mathrm{C} / \mathrm{min}$ heating rate in oxygen and nitrogen atmospheres with a flow rate of $50 \mathrm{ml} / \mathrm{min}$.

\subsection{Tribological Tests}

A Bruker UMT-3 reciprocating ball-on-plate microprocessor-controlled machine was used to perform the tribological (friction and wear) tests. Firstly, 60-min tests were conducted at a load of $60 \mathrm{~N}$ (corresponding to maximum contact pressure of $1.91 \mathrm{GPa}$ ), a frequency of $15 \mathrm{~Hz}$ and stroke length of 4 $\mathrm{mm}$ in the presence of $4 \mathrm{ml}$ of the corresponding lubricant sample. Secondly, load ramp tests were carried out, containing six 5-minute steps (total of 30 minutes) and increasing the load from 20 to $120 \mathrm{~N}$, using the same frequency, stroke length and lubricant volume as the 60-minute tests. Finally, Stribeck curve tests were also carried out, with 16 steps of 5 seconds each under a load of $5 \mathrm{~N}$ (corresponding to maximum contact pressure of $0.83 \mathrm{GPa}$ ), increasing the frequency from 0.1 to $30 \mathrm{~Hz}$ at a rate of 2 Hz/step. The stroke length of $4 \mathrm{~mm}$ and the lubricant volume of $4 \mathrm{ml}$ remained constant. The coefficient of friction was measured during the tests and the wear depth was measured on the disc's surface after 60minute tests using a confocal microscope (Leica DCM 3D). All tests were made under room temperature 
and a relative humidity between 20-30\%. AISI 52100 chrome steel balls with 63 HRC of hardness, 9.5 $\mathrm{mm}$ diameter, and surface finish (Ra) of approximately $0.01 \mu \mathrm{m}$ was used as the upper specimen. AISI 52100 steel discs with $190-210 \mathrm{HV}_{30}$ of hardness and surface finish (Ra) of less than $0.02 \mu \mathrm{m}$ were used as the lower specimen. Before the tribological tests, the balls and discs were ultrasonically cleaned with heptane for 5 minutes, rinsed in ethanol and dried in hot air. All lubricant samples were tested at least three times under each test condition.

\subsection{Surface Characterization}

Before surface characterization, the specimens were also cleaned with heptane and ethanol and then dried in hot air. The wear volume on the discs was measured using a Leica DCM 3D confocal microscope. Surface analysis techniques, scanning electron microscopy (SEM), energy dispersive spectroscopy (EDS) and X-Ray photoelectron spectroscopy (XPS), were used in order to study the lubricant-surface interactions after the 60 -minute tests. $20 \mathrm{kV}$ of acceleration voltage was selected to do the SEM-EDS analysis. The XPS measurements were performed using a SPECS photoelectron spectrometer equipped with a Phoibos hemispheral energy analyzer MDA5 and a monochromatic X-Ray source with an Al anode (energy $1486.6 \mathrm{eV}$ ) at $200 \mathrm{~W}$ and $13 \mathrm{kV}$ and a spot size of $2 \times 0.5 \mathrm{~mm}^{2}$, thus providing spatial resolution for the analysis. The pressure in the analysis chamber was kept below $10^{-8}$ mbar. The energy analyzer was set in a constant pass energy mode and the electromagnetic lenses were set to "small area" value, so the wear scar or the outer surface could be analyzed with a proper spatial resolution. Survey spectra were taken with pass energy $90 \mathrm{eV}$ and energy step $1 \mathrm{eV}$ and high resolution spectra used $30 \mathrm{eV}$ pass energy and $0.1 \mathrm{eV}$ energy step. Mathematical fitting of the spectra was carried out using Shirley-type baseline [51] and a Gaussian (70\%)-Lorentzian (30\%) product as model curve, using CasaXPS software with the Levenberg-Marquardt algorithm [52].

\section{Results and discussion}

The TGA curves of the ionic liquids $\left(\left[\mathrm{P}_{66614}\right]\left[(\mathrm{iC} 8)_{2} \mathrm{PO}_{2}\right]\right.$ and $\left.\left[\mathrm{P}_{66614}\right][\mathrm{BEHP}]\right)$ and the base oil (YUBASE) under oxygen and nitrogen atmospheres are compared in Fig. 1. The base oil has similar thermal behavior under both atmospheres, the oxygen atmosphere being as expected more reactive, a rapid degradation was provoked, with the onset of degradation at a temperature of about $257^{\circ} \mathrm{C}$. But under an inert atmosphere (nitrogen in this case), the degradation was gradual, starting at about $268^{\circ} \mathrm{C}$. Due to their high resistance 
to the pyrolysis (endothermic) process, the ionic liquids showed higher degradation temperatures (293$300^{\circ} \mathrm{C}$ ) than the base oil under the nitrogen atmosphere. However, the overlapping oxidation process (exothermic) that occurs under an oxygen atmosphere provokes slightly lower degradation temperatures $\left(247-248^{\circ} \mathrm{C}\right)$ in the ionic liquids. Finally, the $\left[\mathrm{P}_{66614}\right][\mathrm{BEHP}] \mathrm{IL}$ displayed a two steps degradation curve, probably due to the more reactive phosphate anion type [53].
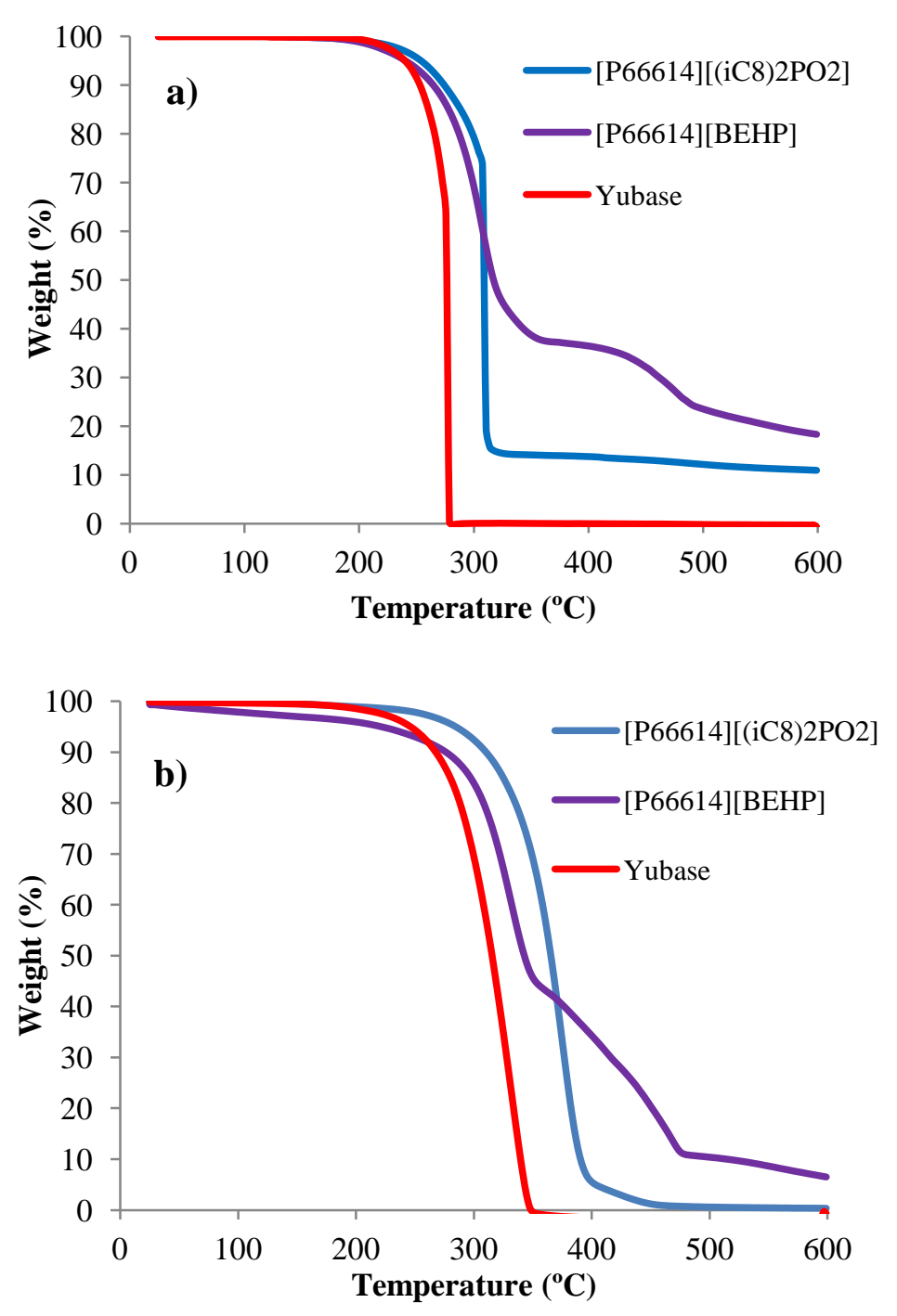

Fig. 1. Thermogravimetric analysis under: (a) $\mathrm{O}_{2}$ atmosphere (b) $\mathrm{N}_{2}$ atmosphere.

Fig. 2 compares the mean friction coefficient of the base oil and the mixtures with ionic liquids and ZDDP in the 60-minute tribological tests. Although the mixtures present some degree of variability, in general all of them have similar and lower mean values than that of the base oil (YUBASE). It is interesting to observe that similar concentrations of phosphorus in the ionic liquids and ZDDP lead to similar friction values, and the $\left[\mathrm{P}_{66614}\right][\mathrm{BEHP}]$ showed less deviation in friction values than the other samples. The better friction behavior of the mixtures at 0.5 and $1 \mathrm{wt} . \%$ of $\left[\mathrm{P}_{66614}\right][\mathrm{BEHP}]$ with regard to 
the ones with $\left[\mathrm{P}_{66614}\right]\left[(\mathrm{iC} 8)_{2} \mathrm{PO}_{2}\right]$ is likely related to the slightly better antifriction properties of the former in a pure state [54].

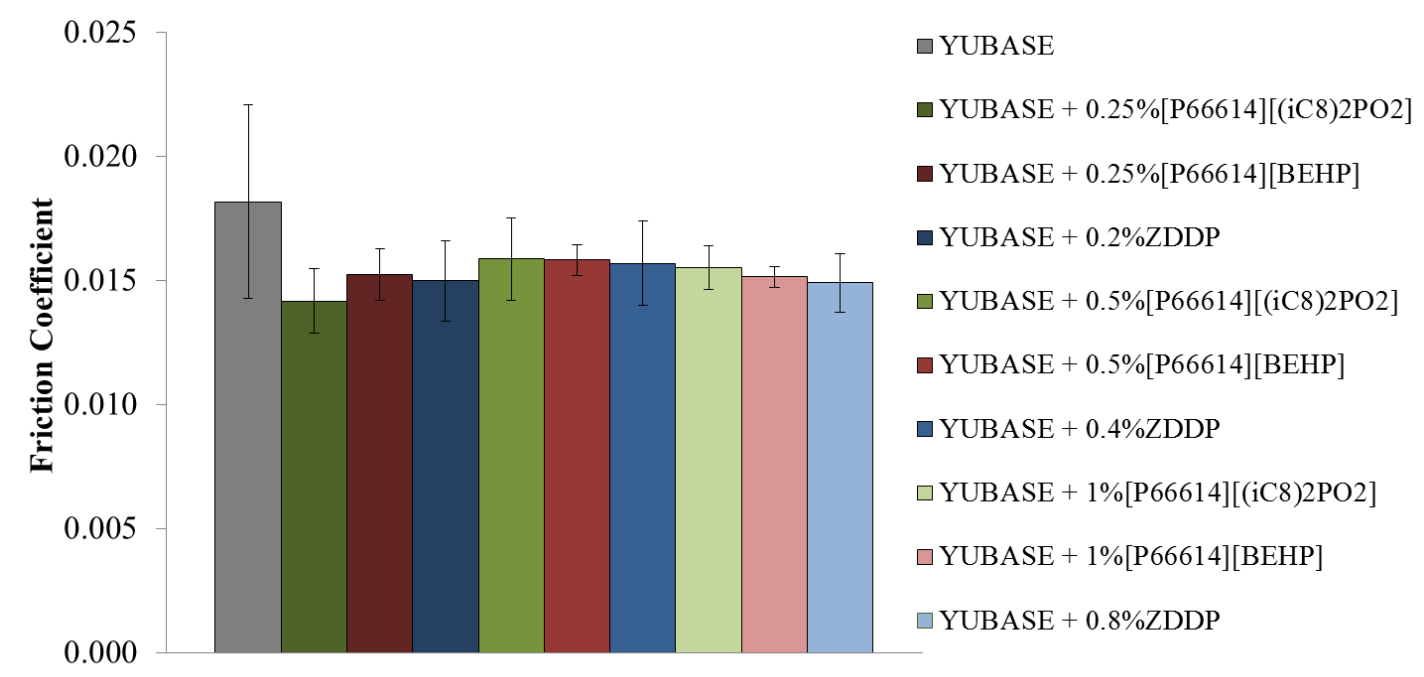

Fig. 2. Mean friction coefficient and deviation in the 60-minute tests.

The evolution of the friction coefficient with testing time also showed that most of the time, the friction values of the mixtures were lower than those of the base oil, Fig. 3.

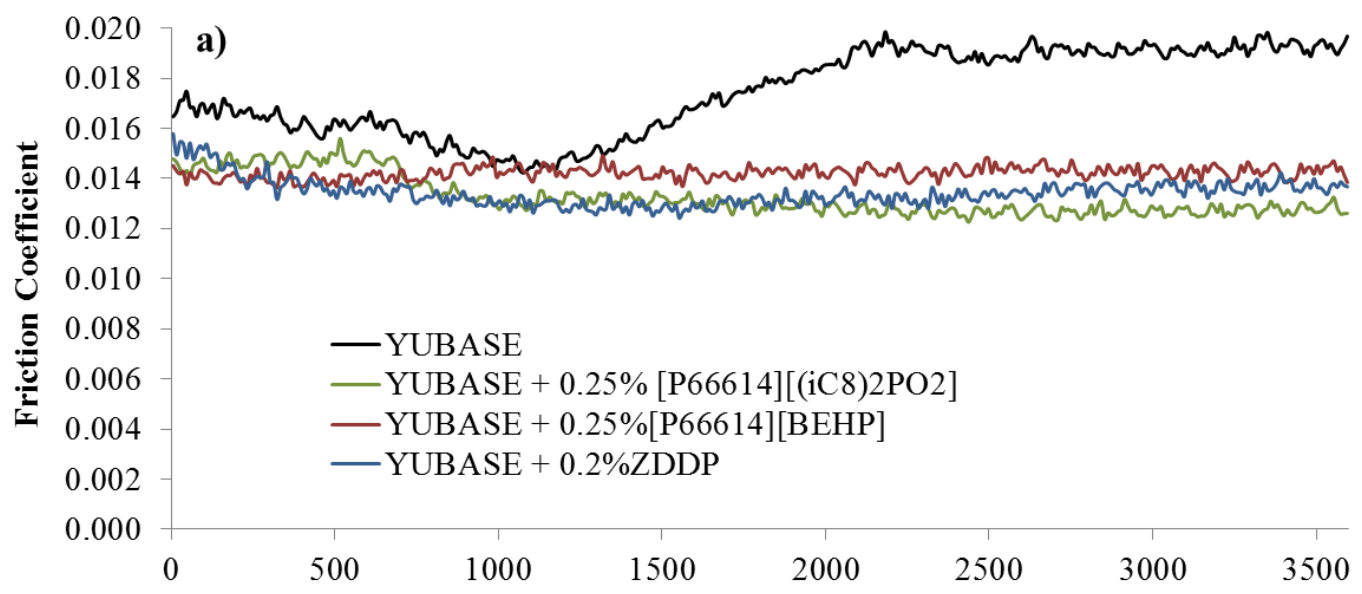

Testing time (s) 

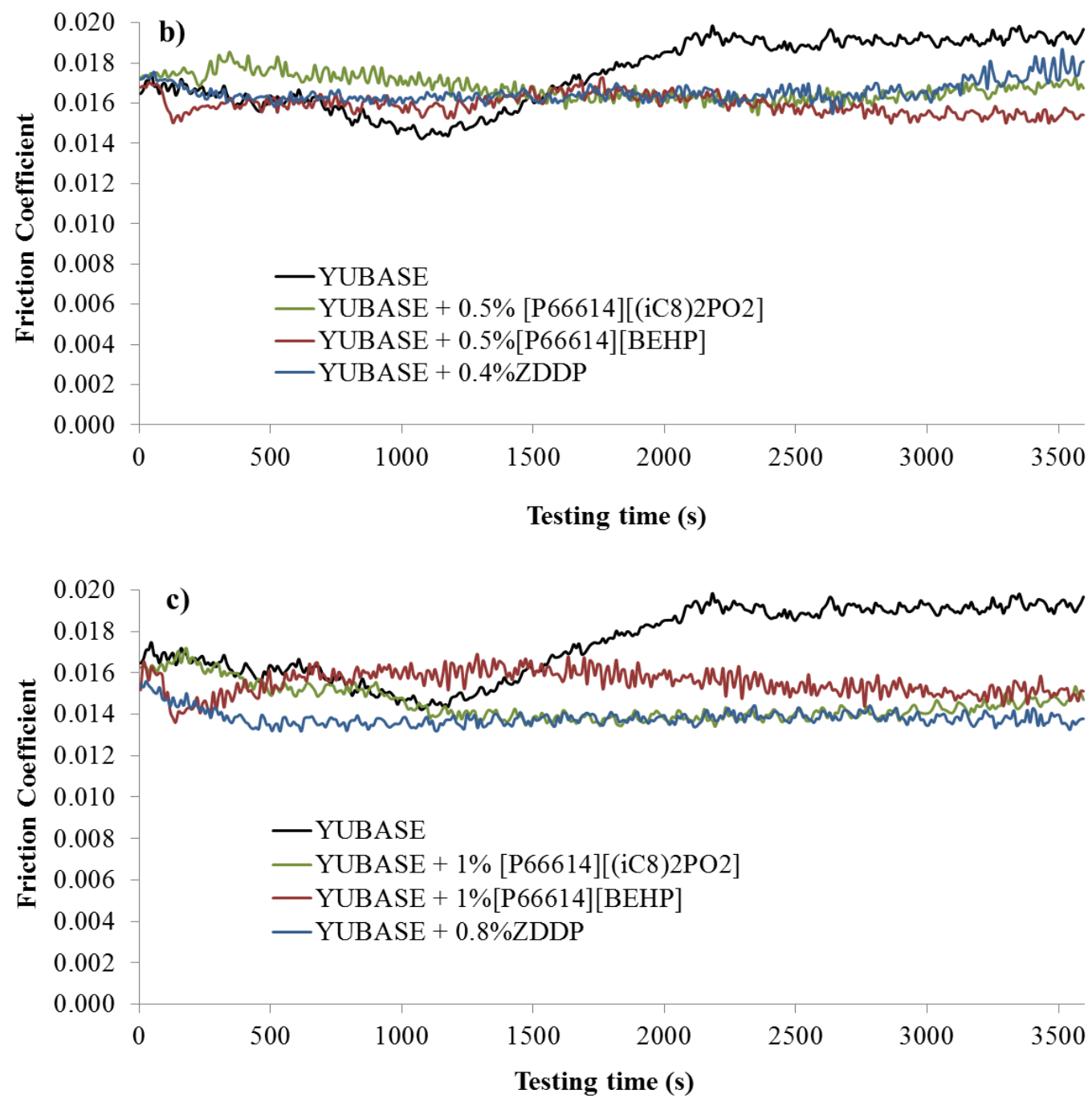

Fig. 3. Friction coefficient behavior versus testing time in the 60 -minute tests.

On the other hand, the results of the load ramp tests, Fig. 4, showed that in general the mixtures had lower friction coefficient under all loads than the base oil and the ZDDP mixtures showed more stable and the lowest friction values. 

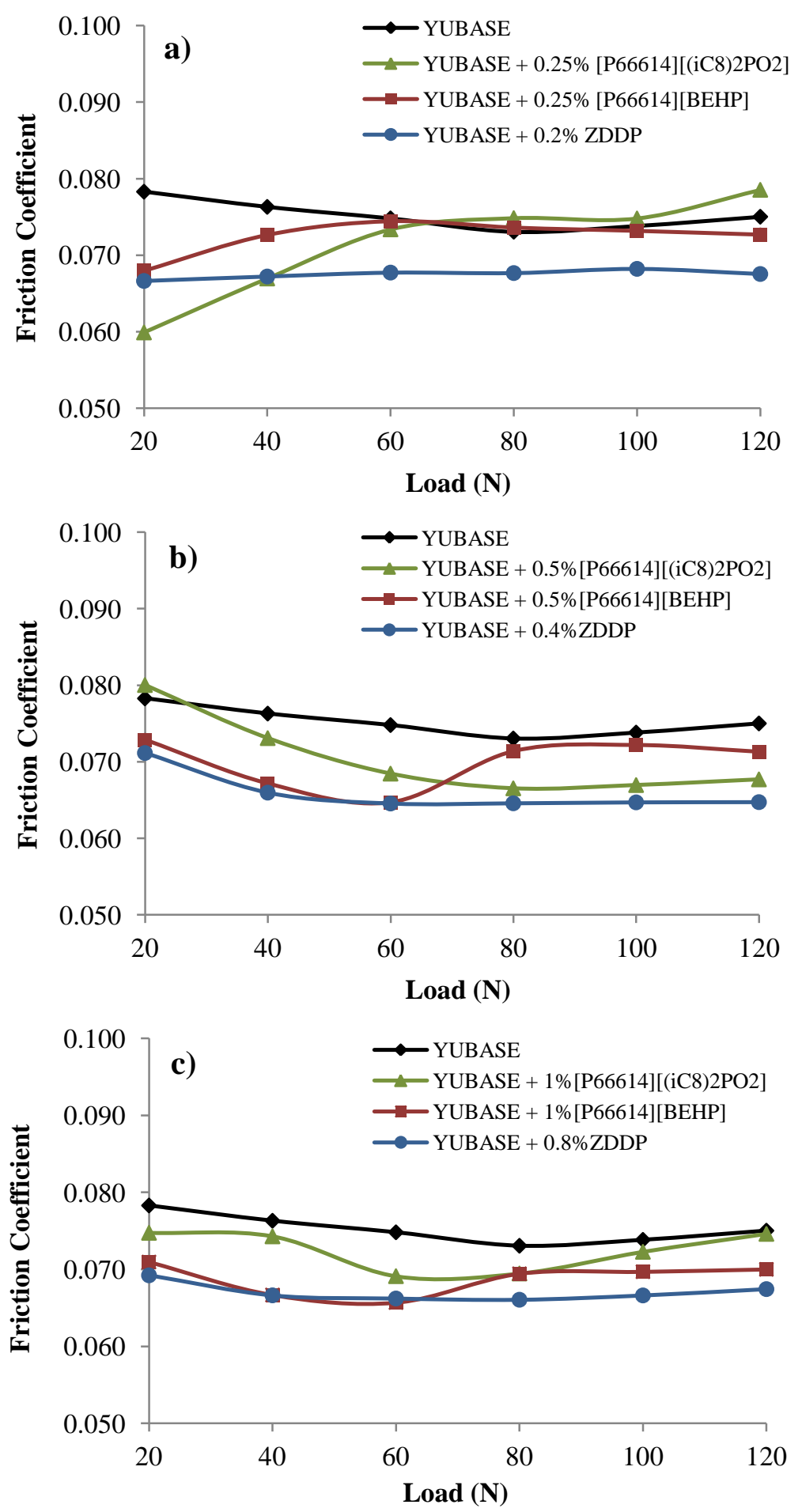

Fig. 4. Friction behavior of the base oil and its mixtures for load ramp tests.

With regard to antiwear behavior, all the mixtures also showed clear wear reduction properties compared to the neat base oil in the 60 -minute tests, Table 3. $\left[\mathrm{P}_{66614}\right]\left[(\mathrm{iC} 8)_{2} \mathrm{PO}_{2}\right]$ ionic liquid showed better wear reduction properties than the $\left[\mathrm{P}_{66614}\right][\mathrm{BEHP}]$, even outperforming their counterpart's mixtures with 0.4 and 0.8 wt. $\%$ of ZDDP. In addition, an increase in the amount of ionic liquid and ZDDP in the mixtures improved, as expected, the antiwear behavior of all samples. 
Table 3. Wear results after 60-minute tests.

\begin{tabular}{|c|c|c|}
\hline \multirow[b]{2}{*}{ Lubricants } & \multicolumn{2}{|c|}{ 60-minute tests } \\
\hline & $\begin{array}{c}\text { Wear volume } \\
\left(\mu \mathrm{m}^{3}\right) \times 10^{6}\end{array}$ & Std. Dev. \\
\hline YUBASE & 19.19507 & 2.45053 \\
\hline YUBASE $+0.25 \%\left[\mathrm{P}_{66614}\right]\left[(\mathrm{iC} 8)_{2} \mathrm{PO}_{2}\right]$ & 9.64876 & 1.30363 \\
\hline YUBASE $+0.25 \%\left[\mathrm{P}_{66614}\right][\mathrm{BEHP}]$ & 14.79553 & 2.35923 \\
\hline YUBASE + 0.2\%ZDDP & 6.92742 & 0.50503 \\
\hline YUBASE + 0.5\% $\left[\mathrm{P}_{66614}\right]\left[(\mathrm{iC} 8)_{2} \mathrm{PO}_{2}\right]$ & 6.01825 & 2.68846 \\
\hline YUBASE $+0.5 \%\left[\mathrm{P}_{66614}\right][\mathrm{BEHP}]$ & 13.58381 & 1.01302 \\
\hline YUBASE + 0.4\%ZDDP & 6.99778 & 1.21469 \\
\hline YUBASE + 1\% $\left[\mathrm{P}_{66614}\right]\left[(\mathrm{iC} 8)_{2} \mathrm{PO}_{2}\right]$ & 4.73603 & 1.22014 \\
\hline YUBASE + 1\%[P 66614$][\mathrm{BEHP}]$ & 8.01298 & 0.60737 \\
\hline YUBASE + 0.8\%ZDDP & 5.33850 & 0.39144 \\
\hline
\end{tabular}

Worn surfaces were examined by using SEM and EDS. The SEM images (Figs. 5-7) showed evidence of adhesive wear and plastic deformation.
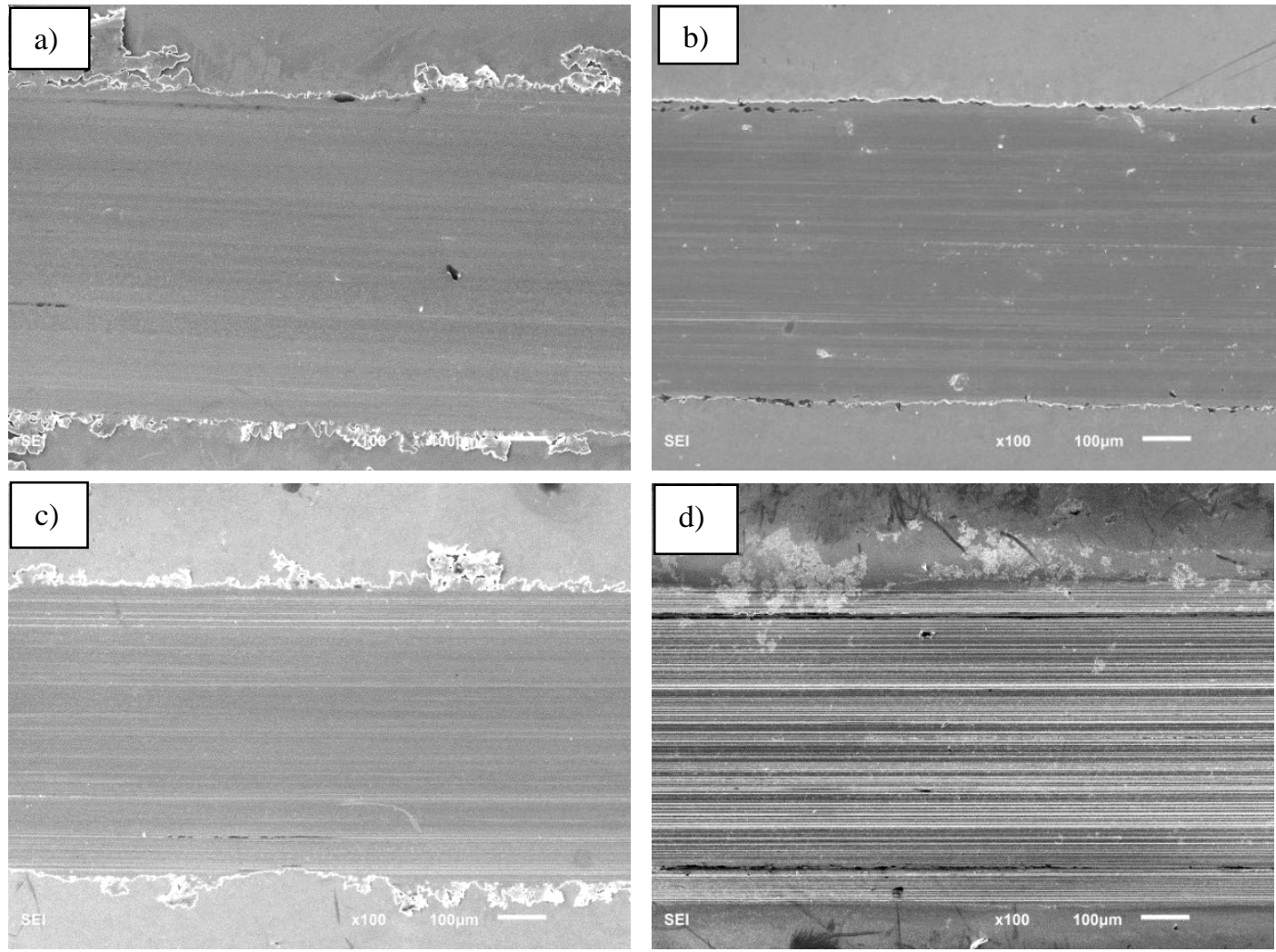

Fig. 5. SEM images taken on worn surfaces after the 60-minute tribological tests made with: (a) neat YUBASE, (b) YUBASE + 0.25\% $\left[\mathrm{P}_{66614}\right]\left[(\mathrm{iC} 8)_{2} \mathrm{PO}_{2}\right]$, (c) YUBASE + 0.5\% $\left[\mathrm{P}_{66614}\right]\left[(\mathrm{iC} 8)_{2} \mathrm{PO}_{2}\right],(\mathrm{d}) \mathrm{YUBASE}+1 \%\left[\mathrm{P}_{66614}\right]\left[(\mathrm{iC} 8)_{2} \mathrm{PO}_{2}\right]$ 

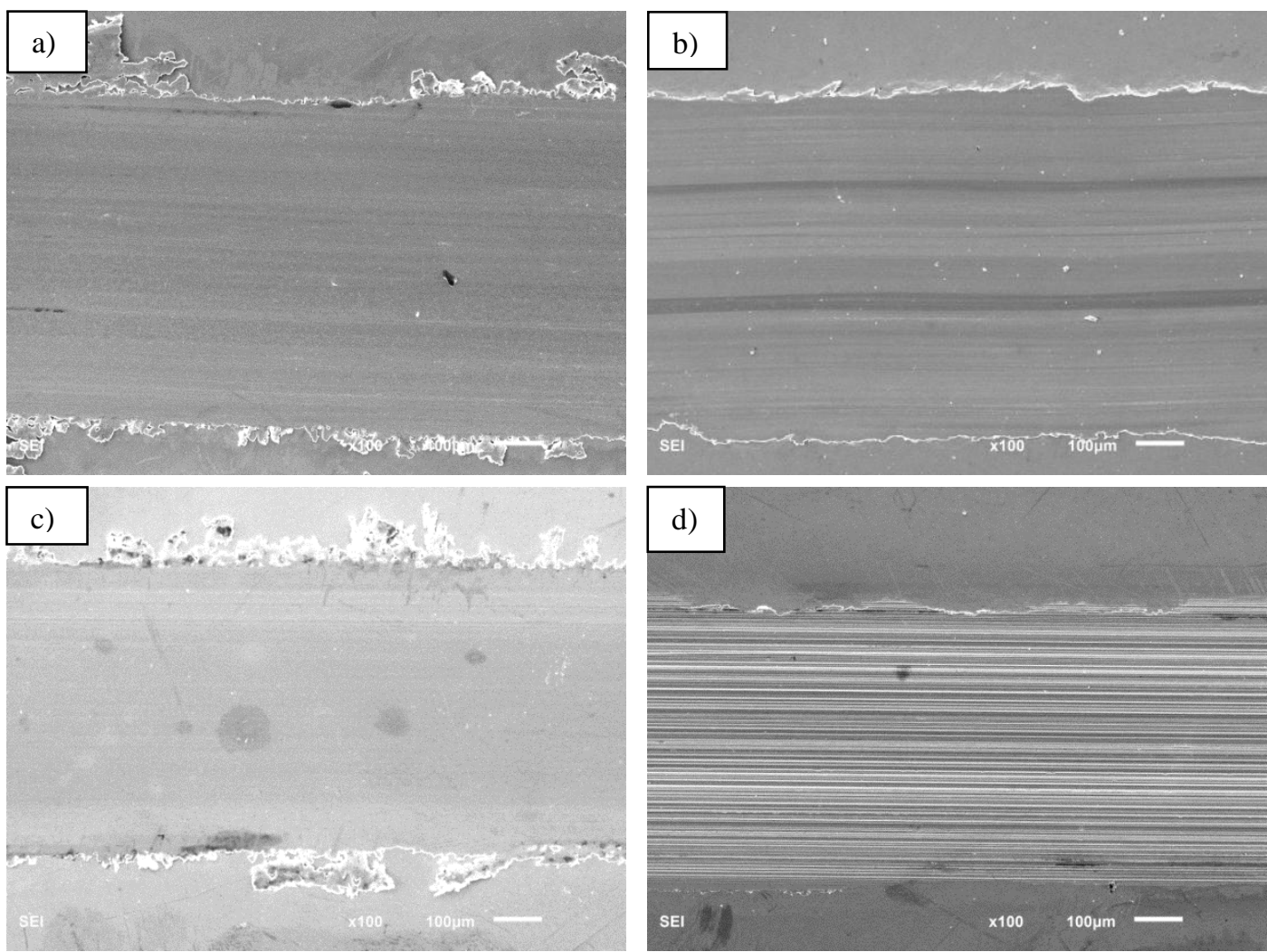

Fig. 6. SEM images taken on worn surfaces after the 60-minute tribological tests made with: (a) neat YUBASE, (b) YUBASE + 0.25\% [P $\left.{ }_{66614}\right]$ [BEHP] (c) YUBASE + 0.5\%[P66614][BEHP], (d) YUBASE + 1\%[P66614][BEHP]
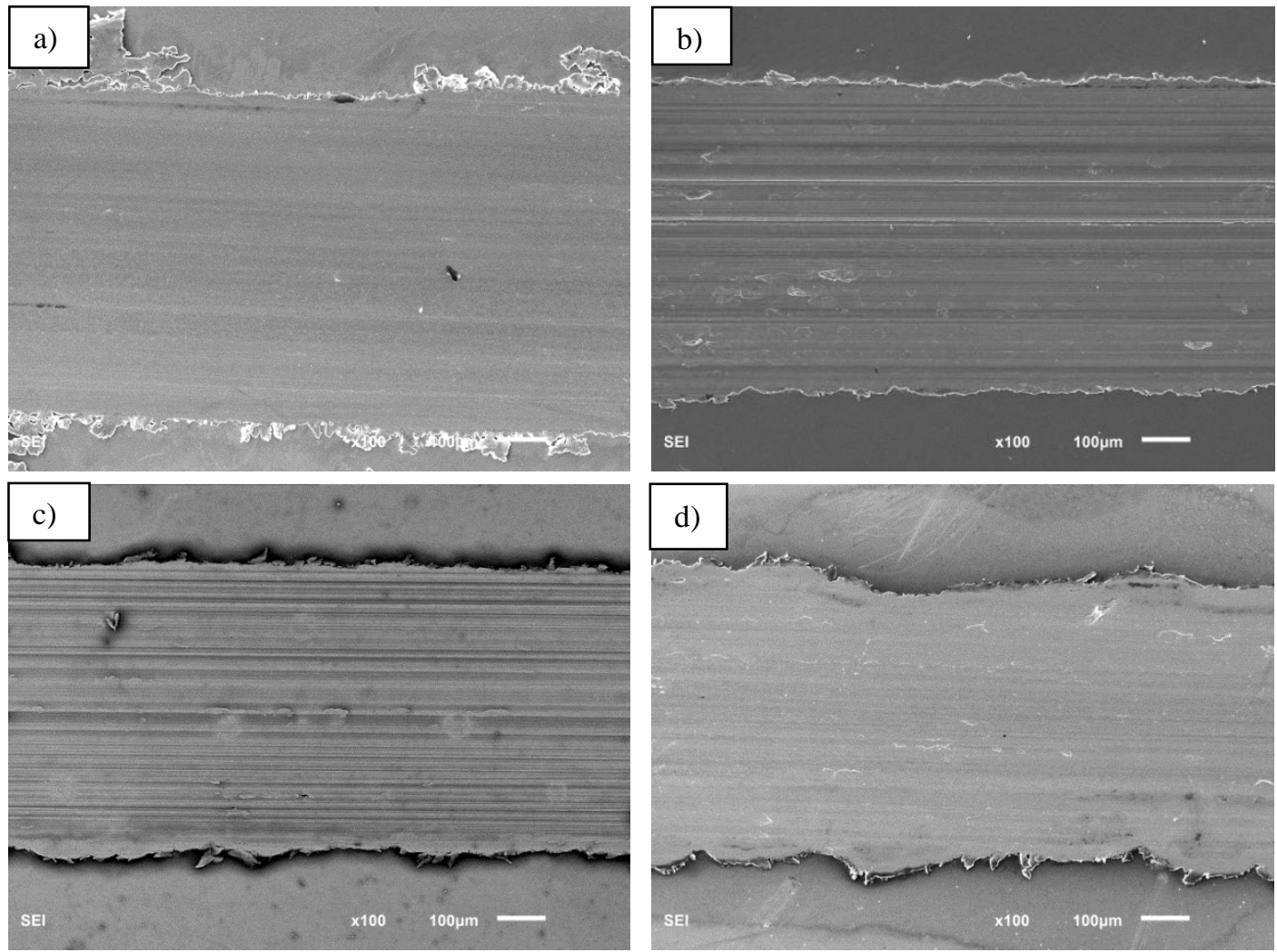
Fig. 7. SEM images taken on worn surfaces after the 60-minute tribological tests made with: (a) neat YUBASE, (b) YUBASE + $0.2 \%$ ZDDP, (c) YUBASE + 0.4\%ZDDP, (d) YUBASE + $0.8 \%$ ZDDP

The EDS spectra (Fig. 8) showed that for the neat base oil the chemical elements found on the worn surface were those present in the steel, while phosphorus was detected for most mixtures. Sulphur and zinc only appear for the ZDDP samples. The rest of the EDS spectra (not shown) had results similar to the examples shown in Fig. 8.

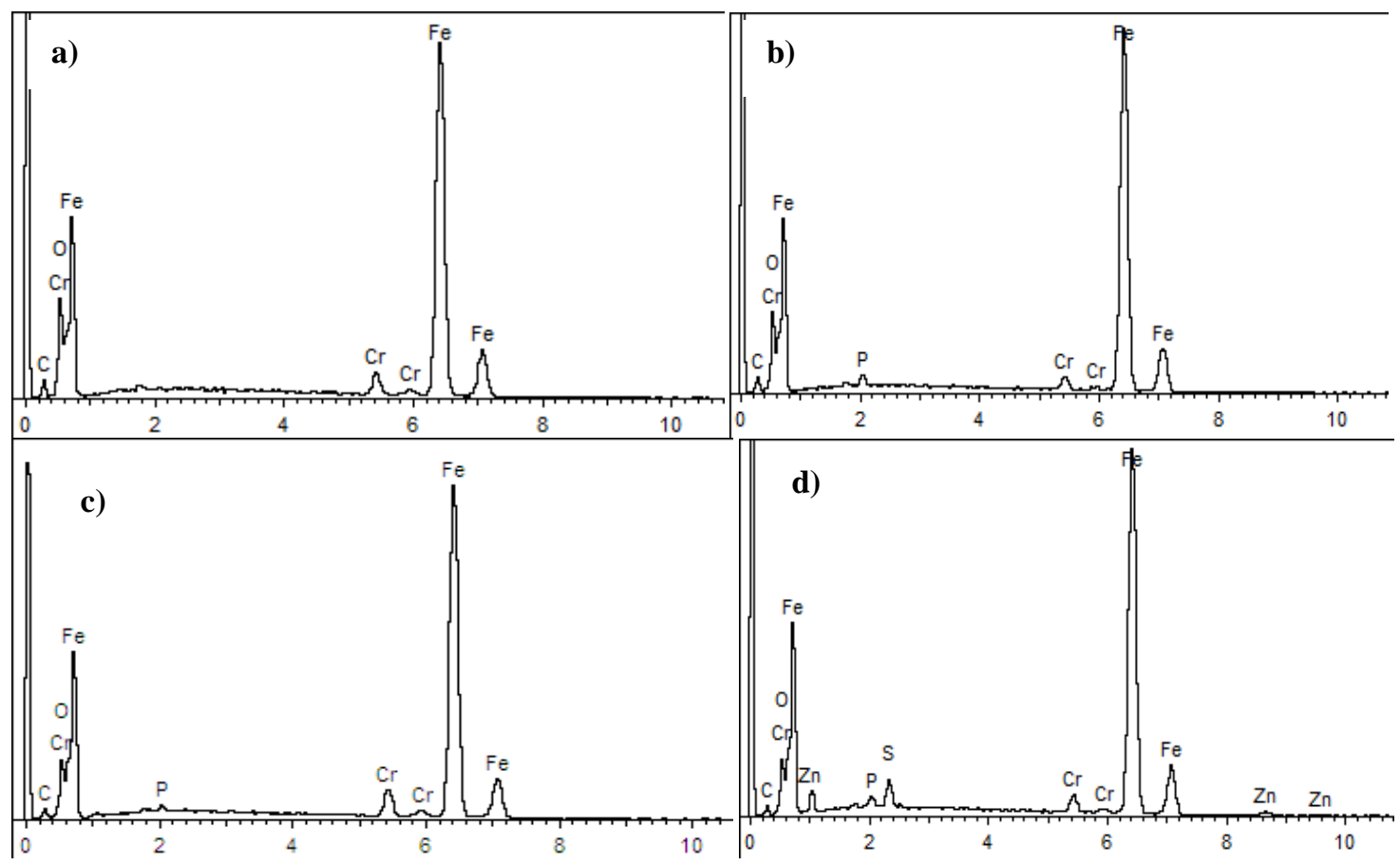

Fig. 8. Results obtained from EDS analysis after 60-minute tribological tests with: (a) neat YUBASE,

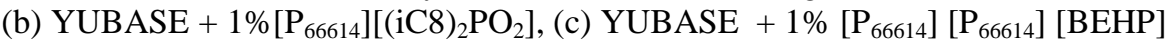
(d) YUBASE + $0.8 \%$ ZDDP.

The Stribeck curve tests (Fig. 9) made under increasing frequency values showed that in general all mixtures perform better than the base oil. The mixtures with both ionic liquids showed similar friction behavior to their ZDDP counterparts. 

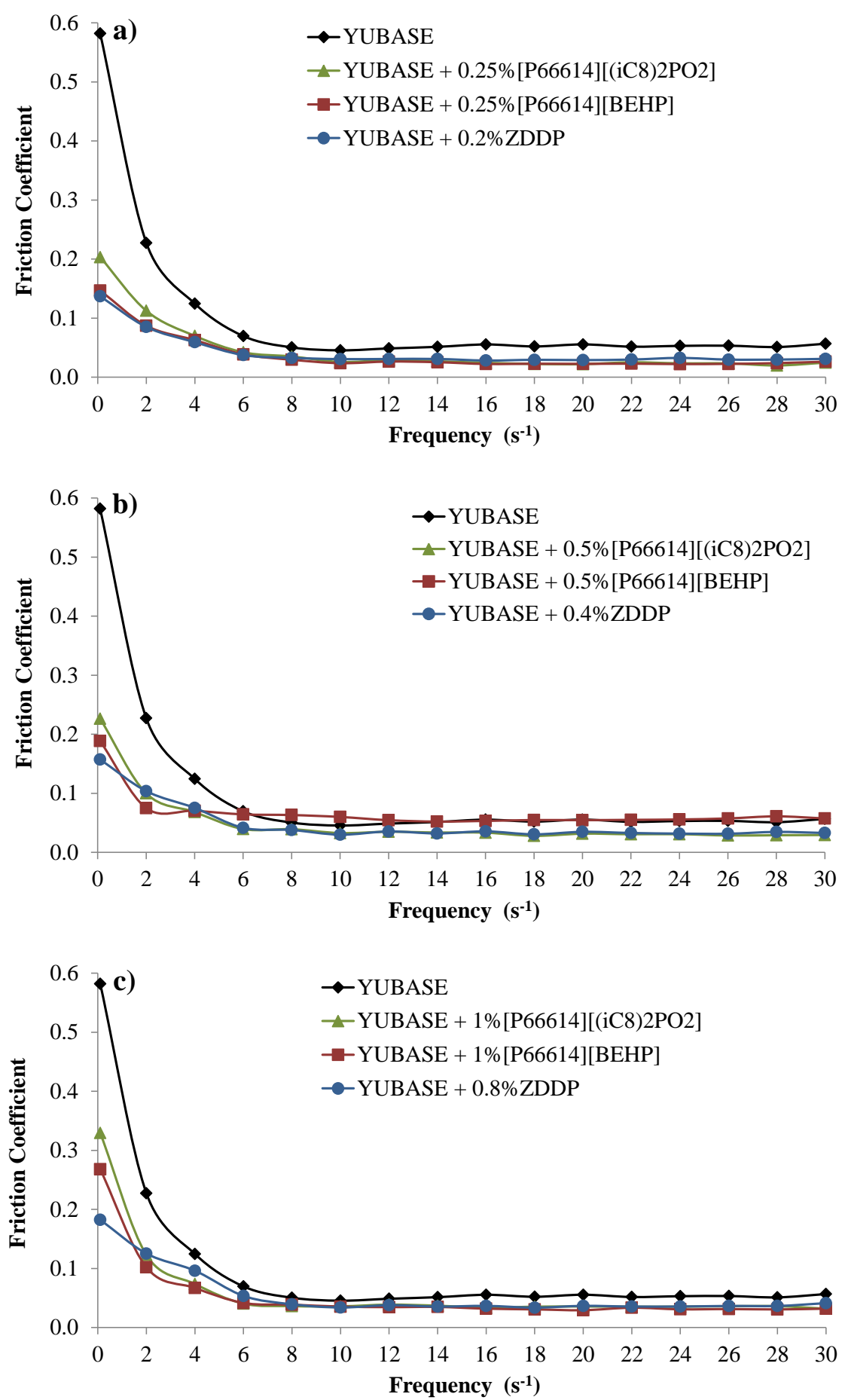

Fig. 9. Stribeck curves for the base oil and its mixtures with the ionic liquids and ZDDP.

The XPS analysis revealed a relevant difference in the behavior of oxygen in samples where either ionic liquid was present. The sample lubricated with neat YUBASE showed two peaks with similar intensities, at $530.5 \mathrm{eV}$ and $532.3 \mathrm{eV}$. As exhibited in Fig. 10, both peaks remain the same for samples lubricated with ZDDP regardless of the concentration. However, lubrication with ionic liquids modifies the ratio of the areas, suggesting an interconversion from the oxygen with higher binding energy to that with lower 
BE. Higher binding energies are usually related to higher oxidation states or to combinations with more electronegative elements. According to information in the NIST database, oxygen at $530.5 \mathrm{eV}$ (the highest band in every sample) can be assigned to iron oxides, either $\mathrm{Fe}_{2} \mathrm{O}_{3}$ or $\mathrm{Fe}_{3} \mathrm{O}_{4}$ [55-57], while the other band can arise from organic oxygen [55]. This hypothesis is in good agreement with the depthprofiling $\mathrm{O} 1 \mathrm{~s}$ analysis. As reflected in Fig. 11, the $\mathrm{O}_{1} \mathrm{~s}_{530} / \mathrm{O}_{1} \mathrm{~s}_{532}$ ratio grows with depth as iron oxide becomes more visible when the organic oxygen is removed. The behavior is the same despite the concentration of $\left[\mathrm{P}_{66614}\right]\left[(\mathrm{iC} 8)_{2} \mathrm{PO}_{2}\right]$.
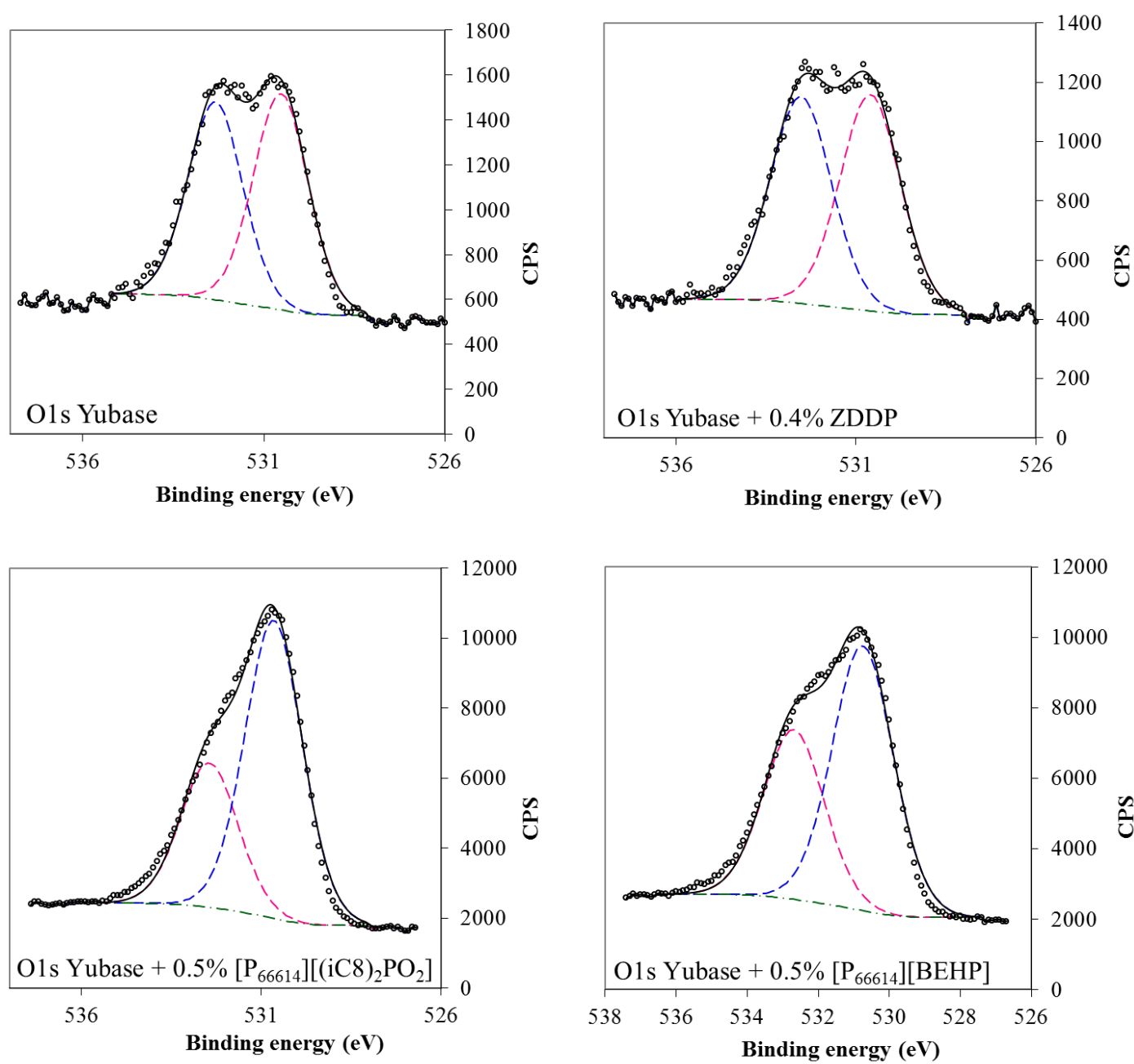

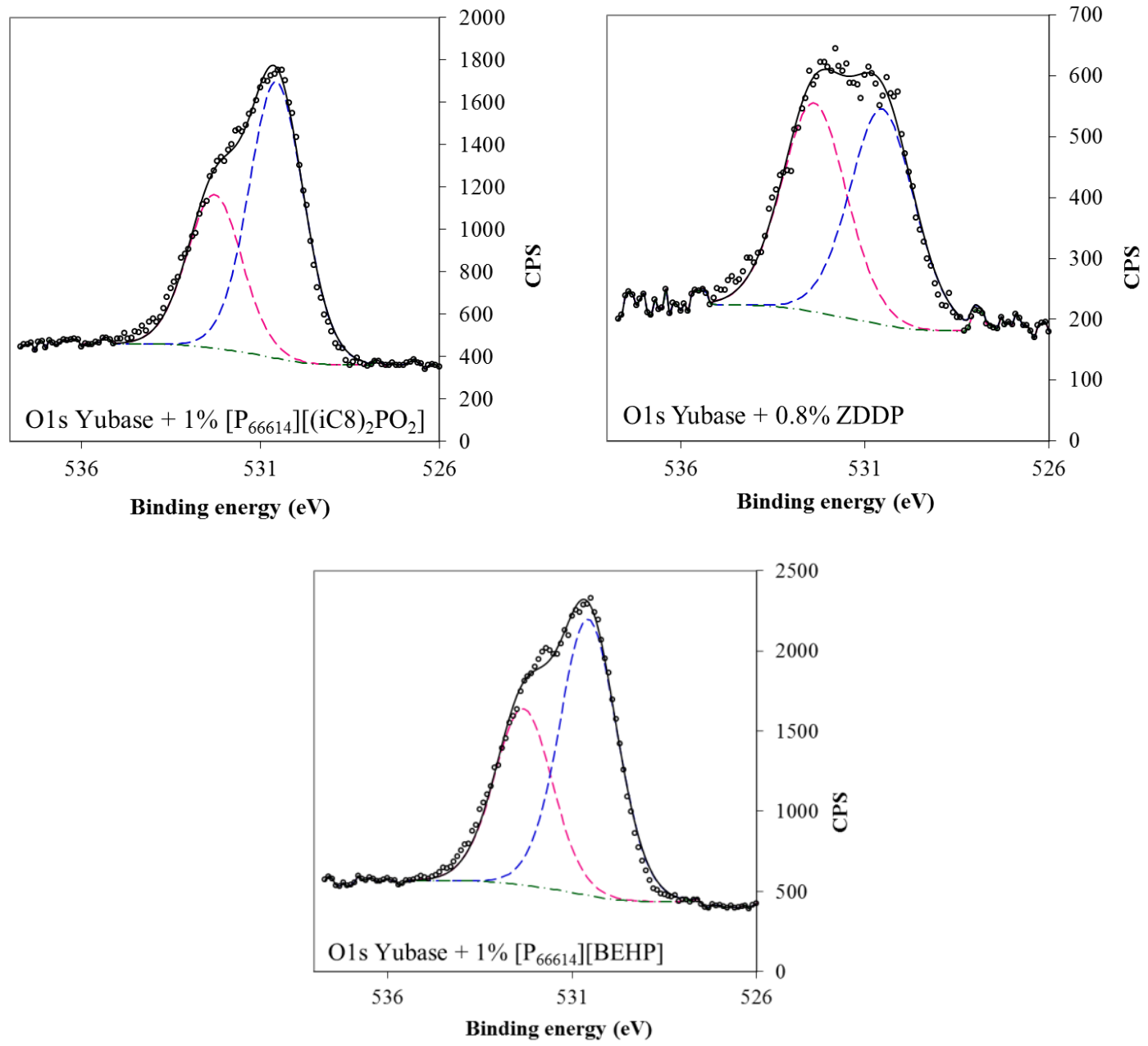

Fig. 10. XPS O1s curves showing the experimental data (circles), fitted curves (dashed lines) and envelope curve (continuous line).

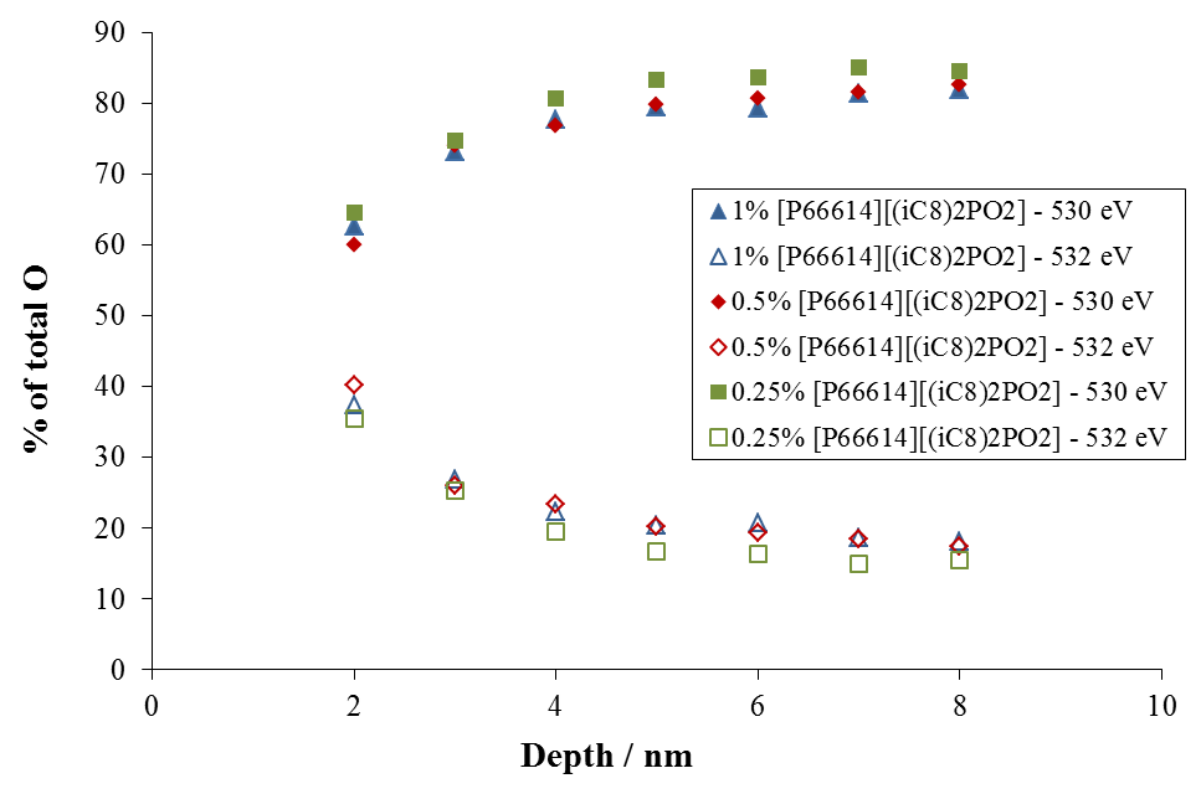

Fig. 11. O1s depth-profiling. 
In order to find out whether the ionic liquid was interacting with the surface, the P2p band was also analyzed with XPS. No P2p band was detected in the YUBASE sample, as no phosphorus is present in the lubricant. However, P2p bands were not detected in ZDDP containing samples either despite the fact that ZDDP is a phosphorus compound. The discrepancies between the XPS and EDS results concerning phosphorus can be attributed to the different sensitivities of these techniques, as well as to the fact that depth-penetration of EDS lies within the micron range whereas XPS is in the nanometer scale. Figure 12 shows $\mathrm{P} 2 \mathrm{p}$ spectra for samples containing $\left[\mathrm{P}_{66614}\right]\left[(\mathrm{iC} 8)_{2} \mathrm{PO}_{2}\right]$ or $\left[\mathrm{P}_{66614}\right][\mathrm{BEHP}]$, where a doublet at ca. $133.3 \mathrm{eV}(\mathrm{P} 2 \mathrm{p} 3 / 2)$ and $134.3 \mathrm{eV}(\mathrm{P} 2 \mathrm{p} 1 / 2)$ could be found. According to the previous literature, iron polyphosphates are expected to be detected in IL lubricated samples [58], but the amount of P detected in the sample was not very high. The binding energy seems to be correlated with the presence of $\mathrm{FePO}_{4}$ which is reported as appearing at $133.7 \mathrm{eV}$ [59]. Analysis of $\mathrm{Fe} 2 \mathrm{p} 3 / 2$ band by depth-profiling of samples with different $\left[\mathrm{P}_{66614}\right]\left[(\mathrm{iC} 8)_{2} \mathrm{PO}_{2}\right]$ concentration reveals the presence of three iron bands at ca. $708 \mathrm{eV}$, $710 \mathrm{eV}$ and $712 \mathrm{eV}$. Identifying these bands is not an easy task, but a plausible explanation would be the assignation to $\mathrm{Fe}, \mathrm{FeO}$ and $\mathrm{Fe}_{2} \mathrm{O}_{3}$ respectively [60-62]. Assuming this, depth-profiling reveals that the relative concentration of $\mathrm{Fe}_{2} \mathrm{O}_{3}$ keeps constant with the depth while the $\mathrm{Fe}$ concentration grows and $\mathrm{FeO}$ decreases. This behavior is the same, regardless of the concentration of the IL. It is interesting to note that the Fe/O ratio does not depend on the IL concentration, but just on the depth. Table 4 shows the Fe/O ratio vs. depth data.

Table 4. Fe/O ratio vs. depth.

\begin{tabular}{cc} 
Depth $(\mathbf{n m})$ & Fe/O \\
\hline 0.0 & 0.8 \\
1.8 & 1.6 \\
3.6 & 2.2 \\
5.4 & 2.2 \\
7.2 & 2.3 \\
10.8 & 2.7 \\
14.4 & 2.6 \\
\hline
\end{tabular}



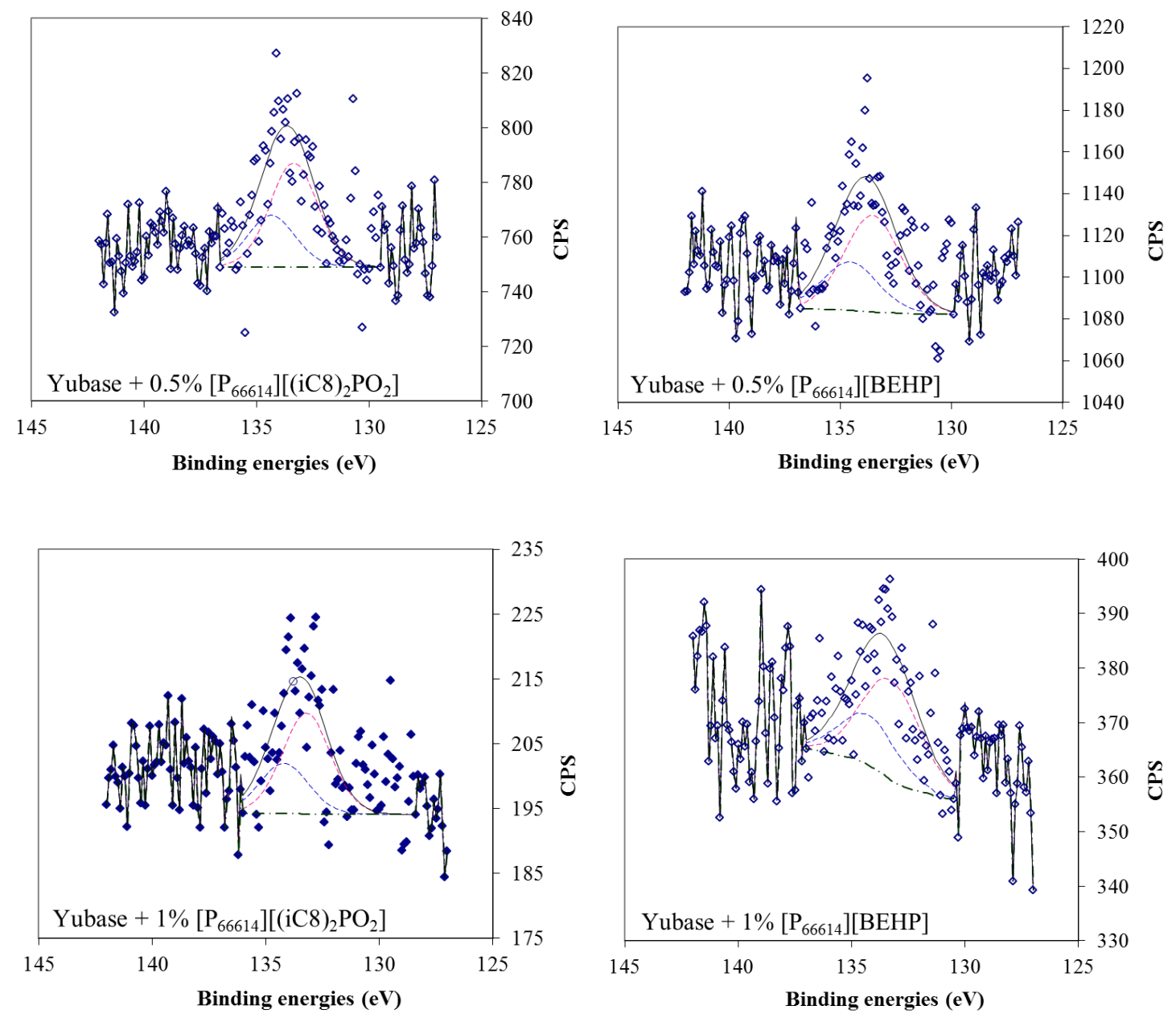

Fig. 12. P2p XPS spectra for IL containing samples.

In the case of samples lubricated with ZDDP, Zn seemed to be incorporated into the surface. Both in the $0.4 \%$ and $0.8 \%$ ZDDP samples, a Zn2p3/2 peak was clearly detected at 1022.9 eV (0.4\% ZDDP) or $1022.6 \mathrm{eV}$ (0.8\% ZDDP), which is usually related to $\mathrm{ZnO}$ [63-64]. The sample lubricated with ZDDP at $0.2 \%$ concentration reveals a very low $\mathrm{Zn} 2 \mathrm{p} 3 / 2$ band at ca. $1022.5 \mathrm{eV}$ which is assumable as $\mathrm{ZnO}$ too. Depth profiling of ZDDP samples reveals a very similar behavior of $\mathrm{Fe}$ and $\mathrm{O}$ to that of samples lubricated with both ionic liquids.

\section{Conclusions}

Two phosphonium cation-based ionic liquids used as lubricant additive at two concentrations $(0.5$ and 1 wt\%) fulfilling the phosphorus concentration limits imposed for motor oils by ILSAC GF-5 were tribologically tested. Mixtures of the base oil using ZDDP as additive reaching equivalent phosphorus 
concentrations to that obtained with the ionic liquids were also tested as comparative samples. The following conclusions can be drawn from the results obtained:

- All the ionic liquids mixtures showed better friction reduction properties than the neat base oil during the 60-minute tests; the mixtures with $\left[\mathrm{P}_{66614}\right][\mathrm{BEHP}]$ showed slightly better friction behavior in terms of variability than the $\left[\mathrm{P}_{66614}\right]\left[(\mathrm{iC} 8)_{2} \mathrm{PO}_{2}\right]$. On the other hand, the antiwear properties of the mixtures were also better than the base oil and the higher the IL concentration the better the tribological behavior, with the $\left[\mathrm{P}_{66614}\right]\left[(\mathrm{iC} 8)_{2} \mathrm{PO}_{2}\right]$ ionic liquid having the best results in this case.

- The ionic liquids used as additive also showed better friction results than the base oil under the load ramp tests. However, the mixtures containing ZDDP exhibited the lowest and more stable friction values.

- The mixtures with ionic liquids also showed, in general, a stable and lower friction coefficient under frequency variation (Stribeck curve) with regard to the base oil.

- SEM and EDS analyses demonstrated the prevalence of adhesive wear and plastic deformation and the presence of phosphorous on the wear surface, especially when the $\left[\mathrm{P}_{66614}\right]\left[(\mathrm{iC} 8)_{2} \mathrm{PO}_{2}\right]$ and ZDDP were used as additive. In the case of ZDDP also the rest of the reactive elements $(\mathrm{Zn}$ and $\mathrm{S})$ were found. XPS results suggest that $\mathrm{Zn}$ in these samples lies in the surface while $\mathrm{P}$ diffuses more deeply, far from the XPS penetration range.

- XPS tests demonstrate that the physicochemical mechanism of lubrication follows a different pathway when using ionic liquids than when using ZDDP. The surface oxygen has a different distribution when using ionic liquids than when using ZDDP. Furthermore, this additive incorporates zinc to the surface.

\section{Acknowledgements}

The authors want to thank to the Spanish Ministry of Economy and Competitiveness and the Foundation for the Promotion in Asturias of Applied Scientific Research and Technology (FICYT) for supporting the DPI2013-48348-C2-1-R and GRUPIN14-023 research projects, respectively. The Units of SEM-EDS and Photoelectron spectroscopy (Scientific-Technical Services) from the University of Oviedo are also acknowledged.

\section{References}


[1] Wassercheid P, Welton T. Ionic Liquid in Synthesis. 2nd ed. Wiley; 2008.

[2] Olivier H. Recent developments in the use of non-aqueous ionic liquids for two-phase catalysis. J Mol Catal A Chem 1999;146:285-9. doi:10.1016/S1381-1169(99)00114-4.

[3] Hagiwara R, Ito Y. Room temperature ionic liquids of alkylimidazolium cations and fluoroanions. J Fluor Chem 2000;105:221-7. doi:10.1016/S0022-1139(99)00267-5.

[4] Rensselar JV. Unleashing the potential of ionic liquids. Tribol Lubr Technol 2010; 4:24-31.

[5] Minami I. Ionic liquids in tribology. Molecules 2009;14:2286-305. doi:10.3390/molecules14062286.

[6] Ye C, Liu W, Chen Y, Yu L. Room-temperature ionic liquids: A novel versatile lubricant. Chem Commun (Camb) 2001:2244-5. doi:10.1039/B106935G.

[7] Somers A, Howlett P, MacFarlane D, Forsyth M. A Review of Ionic Liquid Lubricants. Lubricants 2013;1:3-21. doi:10.3390/lubricants1010003.

[8] Bermúdez MD, Jiménez AE, Sanes J, Carrión FJ. Ionic liquids as advanced lubricant fluids. Molecules 2009;14:2888-908. doi:10.3390/molecules14082888.

[9] Blanco D, González R, Hernández Battez A, Viesca JL, Fernández-González A. Use of ethyldimethyl-2-methoxyethylammonium tris(pentafluoroethyl) trifluorophosphate as base oil additive in the lubrication of TiN PVD coating. Tribol Int 2011;44:645-50. doi:10.1016/j.triboint.2011.01.004.

[10] Viesca JL, Battez AH, González R, Reddyhoff T, Pérez AT, Spikes HA. Assessing boundary film formation of lubricant additivised with 1-hexyl-3-methylimidazolium tetrafluoroborate using ECR as qualitative indicator. Wear 2010;269:112-7. doi:10.1016/j.wear.2010.03.014.

[11] Wang H, Lu Q, Ye C, Liu W, Cui Z. Friction and wear behaviors of ionic liquid of alkylimidazolium hexafluorophosphates as lubricants for steel/steel contact. Wear 2004;256:44-8. doi:10.1016/S0043-1648(03)00255-2.

[12] Mu Z, Liu W, Zhang S, Zhou F. Functional Room-Temperature Ionic Liquids as Lubricants for an Aluminum-on-Steel System. Chem Lett 2004;33:524-525. http://doi.org/10.1246/c1.2004.524.

[13] Phillips BS, Zabinski JS. Ionic liquid lubrication effects on ceramics in a water environment. Tribol Lett 2004;17:533-41. doi:10.1023/B:TRIL.0000044501.64351.68.

[14] González R, Hernández Battez A, Blanco D, Viesca JL, Fernández-González A. Lubrication of TiN, CrN and DLC PVD coatings with 1-butyl-1- methylpyrrolidinium tris(pentafluoroethyl)trifluorophosphate. Tribol Lett 2010;40:269-77. doi:10.1007/s11249-0109674-5. 
[15] Liu W, Ye C, Gong Q, Wang H, Wang P. Tribological performance of room-temperature ionic liquids as lubricant. Tribol Lett 2002;13:81-5. doi:10.1023/A:1020148514877.

[16] Chen YM, Zeng ZX, Yang SR, Zhang JY. The tribological performance of BCN films under ionic liquids lubrication. Diam Relat Mater 2009;18:20-6. doi:10.1016/j.diamond.2008.07.023.

[17] Torimoto T, Tsuda T, Okazaki KI, Kuwabata S. New frontiers in materials science opened by ionic liquids. Adv Mater 2010;22:1196-221. doi:10.1002/adma.200902184.

[18] Jiménez AE, Bermúdez MD. Imidazolium ionic liquids as additives of the synthetic ester propylene glycol dioleate in aluminium-steel lubrication. Wear 2008;265:787-98. doi:10.1016/j.wear.2008.01.009.

[19] Otero I, López ER, Reichelt M, Fernández J. Friction and anti-wear properties of two tris(pentafluoroethyl) trifluorophosphate ionic liquids as neat lubricants. Tribol Int 2014;70:104-11. doi:10.1016/j.triboint.2013.10.002.

[20] Blanco D, Battez AH, Viesca JL, González R, Fernández-González A. Lubrication of CrN coating with ethyl-dimethyl-2-methoxyethylammonium tris(pentafluoroethyl)trifluorophosphate ionic liquid as additive to PAO 6. Tribol Lett 2011;41:295-302. doi:10.1007/s11249-010-9714-1.

[21] Viesca JL, García A, Hernández Battez A, González R, Monge R, Fernández-González A, et al. FAP- anion ionic liquids used in the lubrication of a steel-steel contact. Tribol Lett 2013;52:431-7. doi:10.1007/s11249-013-0226-7.

[22] Qu J, Truhan JJ, Dai S, Luo H, Blau PJ. Ionic liquids with ammonium cations as lubricants or additives. Tribol Lett 2006;22:207-14. doi:10.1007/s11249-006-9081-0.

[23] Jiménez AE, Bermúdez MD, Iglesias P, Carrión FJ, Martínez-Nicolás G. 1-N-alkyl -3methylimidazolium ionic liquids as neat lubricants and lubricant additives in steel-aluminium contacts. Wear 2006;260:766-82. doi:10.1016/j.wear.2005.04.016.

[24] Qu J, Blau PJ, Dai S, Luo H, Meyer HM. Ionic Liquids as Novel Lubricants and Additives for Diesel Engine Applications. Tribol Lett 2009;35:181-9. doi:10.1007/s11249-009-9447-1.

[25] Mistry K, Fox MF, Priest MJ. Lubrication of an Electroplated Nickel Matrix Silicon Carbide Coated Eutectic Aluminium-Silicon Alloy Automotive CylinderBore with an Ionic Liquid as a Lubricant Additive. Eng Tribol 2009;223:563-69. doi: 10.1243/13506501JET562.

[26] Lu RG, Nanao H, Kobayashi K, Kubo T, Mori SJ. Effect of Lubricant Additives on Tribochemical Decomposition of Hydro- carbon Oil on Nascent Steel Surfaces. J Jpn Petrol Inst 2010;53:55- 60. 
[27] Schneider A, Brenner J, Tomastik C, Franek F. Capacity of selected ionic liquids as alternative EP/AW. Lubr Sci 2010;22:215-23. doi:10.1002/ls.

[28] Qu J, Bansal DG, Yu B, Howe JY, Luo H, Dai S, et al. Antiwear performance and mechanism of an oil-miscible ionic liquid as a lubricant additive. ACS Appl Mater Interfaces 2012;4:997-1002. doi:10.1021/am201646k.

[29] Yu B, Bansal DG, Qu J, Sun X, Luo, H, Dai S, Smolenski, DJ. Oil-miscible and non-corrosive phosphonium-based ionic liquids as candidate lubricant additives. Wear 2012;289:58-64. http://doi.org/10.1016/j.wear.2012.04.015

[30] Somers AE, Khemchandani B, Howlett PC, Sun J, Macfarlane DR, Forsyth M. Ionic liquids as antiwear additives in base oils: Influence of structure on miscibility and antiwear performance for steel on aluminum. ACS Appl Mater Interfaces 2013;5:11544-53. doi:10.1021/am4037614.

[31] Jiménez AE, Bermúdez MD. Ionic liquids as lubricants for steel-aluminum contacts at low and elevated temperatures. Tribol Lett 2007;26:53-60. doi:10.1007/s11249-006-9182-9.

[32] Battez AH, González R, Viesca JL, Blanco D, Asedegbega E, Osorio A. Tribological behaviour of two imidazolium ionic liquids as lubricant additives for steel/steel contacts. Wear 2009;266:12248. doi:10.1016/j.wear.2009.03.043.

[33] Yao M, Liang Y, Xia Y, Zhou F. Bisimidazolium ionic liquids as the high-performance antiwear additives in poly(ethylene glycol) for steel-steel contacts. ACS Appl Mater Interfaces 2009;1:46771. doi:10.1021/am800132z.

[34] Cai M, Liang Y, Yao M, Xia Y, Zhou F, Liu W. Imidazolium ionic liquids as antiwear and antioxidant additive in poly(ethylene glycol) for steel/steel contacts. ACS Appl Mater Interfaces 2010;2:870-6. doi:10.1021/am900847j.

[35] Cai M, Liang Y, Zhou F, Liu W. Anticorrosion Imidazolium Ionic Liquids as the Additive in Poly(Ethylene Glycol) for Steel/Cu-Sn Alloy Contacts. Faraday Discuss 2012;156:147-57.

[36] Zhang H, Xia Y, Yao M, Jia Z, Liu Z. The Influences of Methyl Group at C2 Position in Imidazolium Ring on Tribological Properties. Tribol Lett 2009;36:105-11. doi:10.1007/s11249009-9465-z.

[37] Jiménez AE, Bermúdez MD. Short alkyl chain imidazolium ionic liquid additives in lubrication of three aluminium alloys with synthetic ester oil. Tribol - Mater Surfaces Interfaces 2012;6:109-15. doi:10.1179/1751584X12Y.0000000011. 
[38] Kronberger M, Pejakovic V, Gabler C, Kalin M. How anion and cation species influence the tribology of a green lubricant based on ionic liquids. Proc Inst Mech Eng Part J J Eng Tribol 2012;226:933-51. doi:10.1177/1350650112459012.

[39] Pejaković V, Kronberger M, Kalin M. Influence of temperature on tribological behaviour of ionic liquids as lubricants and lubricant additives. Lubr Sci 2014;26:107-15. doi:10.1002/1s.1233.

[40] Pejakovic V, Kronberger M, Mahrova M, Vilas M, Tojo E, Kalin M. Pyrrolidinium sulfate and ammonium sulfate ionic liquids as lubricant additives for steel/steel contact lubrication. Proc Inst Mech Eng Part J J Eng Tribol 2012;226:923-32. doi:10.1177/1350650112448978.

[41] Fraser KJ, MacFarlane DR. Phosphonium-based ionic liquids: An overview. Aust J Chem 2009;62:309-21. doi:10.1071/CH08558.

[42] Zhou F, Liang Y, Liu W. Ionic liquid lubricants: Designed chemistry for engineering applications. Chemical Society Reviews 2009;38(9), 2590-2599. http://doi.org/10.1039/b817899m.

[43] Barnhill WC, Qu J, Luo H, Meyer HM, Ma C, Chi M, et al. Phosphonium-Organophosphate Ionic Liquids as Lubricant Additives : Effects of Cation Structure on Physicochemical and Tribological Characteristics. ACS Appl Mater Interfaces 2014;6:22585-93.

[44] Qu J, Luo H, Chi M, Ma C, Blau PJ, Dai S, Viola MB. Comparison of an oil-miscible ionic liquid and ZDDP as a lubricant anti-wear additive. Tribol Int 2014;71:88-97. http://doi.org/10.1016/j.triboint.2013.11.010.

[45] Zhou Y, Graham TW, Luo H, Leonard DN, Qu J. Ionic Liquids Composed of Phosphonium Cations and Organophosphate, Carboxylate, and Sulfonate Anions as Lubricant Antiwear Additives. Langmuir 2014;30:13301-11. doi:dx.doi.org/10.1021/la5032366.

[46] Qu J, Barnhill WC, Luo H, Meyer HM, Leonard DN, Landauer AK, Kheireddin B, Gao H, Papke BL, Dai S. Synergistic effects between phosphonium-alkylphosphate ionic liquids and zinc dialkyldithiophosphate (ZDDP) as lubricant additives. Adv Mater. 2015;27(32):4767-74. doi: 10.1002/adma.201502037.

[47] Totolin V, Minami I, Gabler C, Brenner J, Dörr N. Lubrication mechanism of phosphonium phosphate ionic liquid additive in alkylborane-imidazole complexes. Tribol Lett 2014;53:421-32. doi:10.1007/s11249-013-0281-0. 
[48] Otero I, López ER, Reichelt M, Villanueva M, Salgado J, Fernández J. Ionic liquids based on phosphonium cations as neat lubricants or lubricant additives for a steel/steel contact. ACS Appl Mater Interfaces 2014;6:13115-28. doi:10.1021/am502980m.

[49] Khemchandani B, Somers A, Howlett P, Jaiswal AK, Sayanna E, Forsyth M. A biocompatible ionic liquid as an antiwear additive for biodegradable lubricants. Tribol Int 2014;77:171-7. doi:10.1016/j.triboint.2014.04.016.

[50] Canter N. GF-6, PC-11 and dexos $1^{\mathrm{TM}}$ : New engine oil specifications mean new additive challenges. Tribol \& Lubr Tech 2015;9:10-26.

[51] Shirley DA. High-resolution x-ray photoemission spectrum of the valence bands of gold. Phys Rev B 1972;5:4709-14. doi:10.1103/PhysRevB.5.4709.

[52] Åberg ER, Gustavsson AGT. Design and evaluation of modified simplex methods. Anal Chim Acta 1982;144:39-53. doi:10.1016/S0003-2670(01)95518-7.

[53] Green MD, Schreiner C, Long TE. Thermal, Rheological, and Ion-Transport Properties of Phosphonium-Based Ionic Liquids. J Phys Chem 2011:13829-35.

[54] Hernández Battez A, Bartolomé M, Blanco D, Viesca JL, Fernández-González A, González R. Phosphonium cation-based ionic liquids as neat lubricants: Physicochemical and tribological performance. Tribo. Int. 2016;95:118-131. doi:10.1016/j.triboint.2015.11.015.

[55] NIST Database: http://srdata.nist.gov/xps/Default.aspx, last accessed 18th november 2015.

[56] Paparazzo E. XPS and Auger spectroscopy studies on mixtures of the oxides $\mathrm{SiO}_{2}, \mathrm{Al}_{2} \mathrm{O}_{3}, \mathrm{Fe}_{2} \mathrm{O}_{3}$ and $\mathrm{Cr}_{2} \mathrm{O}_{3}$. J Electron Spectros Relat Phenomena 1987;43:97-112. doi:10.1016/03682048(87)80022-1.

[57] Marcus P, Grimal JM. The anodic dissolution and passivation of NiCrFe alloys studied by ESCA. Corros Sci 1992;33:805-14. doi:10.1016/0010-938X(92)90113-H.

[58] Sharma V, Gabler C, Doerr N, Aswath PB. Mechanism of tribofilm formation with P and S containing ionic liquids. Tribol Int 2015;92:353-64. doi:10.1016/j.triboint.2015.07.009.

[59] Dekiouk M, Boisdron N, Pietrzyk S, Barbaux Y, Grimblot J. Kinetic investigation of the oxidative dehydrogenation of isobutyric acid on a Fe-P-O catalyst: role of water. Appl Catal A Gen 1992;90:61-72. doi:10.1016/0926-860X(92)80248-B.

[60] Siriwardene RV, Cook JMJ. Interactions of SO2 with sodium deposited on silica. J. Colloid Interface Sci. 1985;108:414-22. doi:10.1016/0021-9797(85)90280-2. 
[61] Allen GC, Curtis MT, Hooper AJ, Tucker PM. X-Ray photoelectron spectroscopy of iron-oxygen systems. J. Chem. Soc. Dalton Trans. 1974; 1525-30. doi: 10.1039/DT9740001525.

[62] Mills P, Sullivan JL. A study of the core level electrons in iron and its three oxides by means of Xray photoelectron spectroscopy. J. Phys. D: Appl. Phys. 1983;16:723-32. doi: 10.1088/00223727/16/5/005.

[63] Dake LS, Baer DR, Zachara JM. Auger parameter measurements of zinc compounds relevant to zinc transport in the environment. Surf. Interface Anal. 1989;14:71-5. doi:10.1002/sia.740140115.

[64] Gaarenstroom SW, Winograd M. Initial and final state effects in the ESCA spectra of cadmium and silver oxides, J. Chem. Phys. 1977;67:3500. http://dx.doi.org/10.1063/1.435347. 